\section{DOMINICAN \\ UNIVERSITY \\ of CALIFORNIA}

\section{Dominican Scholar}

Graduate Master's Theses, Capstones, and

Culminating Projects

2003

\title{
Meeting the Needs of International Students at Dominican University of California
}

https://doi.org/10.33015/dominican.edu/2003.edu.01

Lisa Haydon

Dominican University of California

Survey: Let us know how this paper benefits you.

\section{Recommended Citation}

Haydon, Lisa, "Meeting the Needs of International Students at Dominican University of California" (2003). Graduate Master's Theses, Capstones, and Culminating Projects. 161.

https://doi.org/10.33015/dominican.edu/2003.edu.01 


\section{Title Page}

\section{Meeting the Needs of International Students at Dominican University of California Part I}

\section{Lisa Haydon}

Submitted in Partial Fulfillment of the $\operatorname{Re}\lceil$ uirements for the Degree

Master of Science in $\square$ ducation: Teacher Leadership

Division of $\square$ ducation

School of $\square$ usiness, $\square$ ducation, and Leadership

Dominican University of California

San Rafael, C

May 2003 


\section{Signature Sheet}

This thesis, written under the direction of the candidate's thesis advisor and approved by the Chair of the Master's program, has been presented to and accepted by the Faculty of Education in partial fulfillment of the requirements for the degree of Master of Science. The content and research methodologies presented in this work represent the work of the candidate alone.

Lisa Haydon

May 7, 2003

Candidate

Madalienne Peters, Ed.D.

May 7, 2003

Thesis Advisor

Madalienne Peters, Ed.D.

May 7, 2003

Director, Graduate Studies

Division of Education 
$\square \mathrm{c} \square$ no $\square$ ledgments

I $\square$ ould li $\ulcorner$ e to than $\square$ the follo $\square$ ing individuals at Dominican University of California for their guidance, support, and encouragement: Dr. $\square$ es $\square$ oung, Dr. $\square \mathrm{d} \square$ ard $\square$ uja $\square \mathrm{a}$, Dr. Madalienne Peters, Dr. Suresh $\square$ ppavoo, $\sqsubset$ enny Li, and $\square$ veril Robertson.

I $\square$ ould also li $\sqsubset$ e to ac $\square$ no $\square$ ledge my father, Dr. $\sqsubset$ erome Haydon, and my husband, Rendell $\square$ o $\square$ er, for their continuing support for my education, and career and personal development. 
Table of Contents

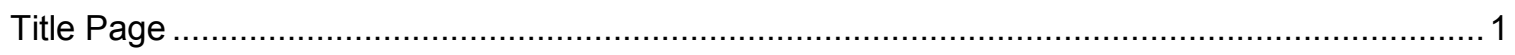

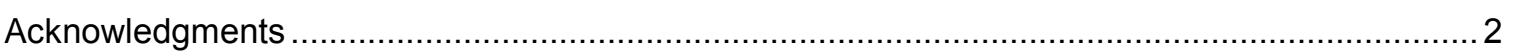

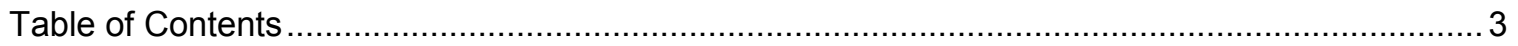

$\square$ bstract

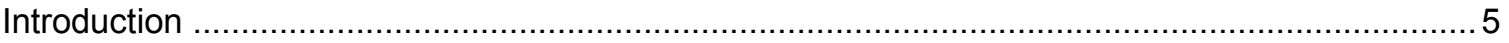

Statement of Problem

Purpose Statement

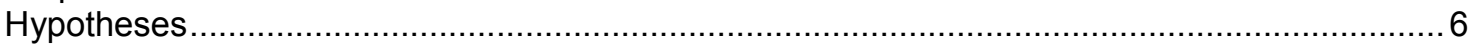

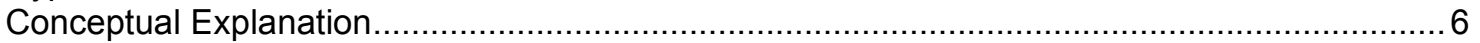

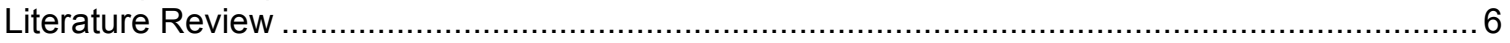

Challenges and Stresses Faced by International Students in the United States .................. 10

Components of Successful International Programs at Post Secondary Institutions ..............1 1

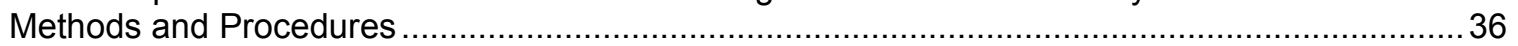

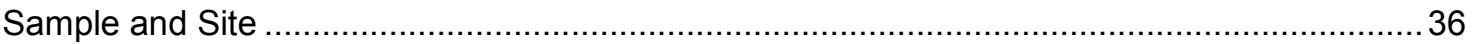

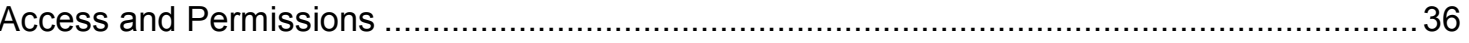

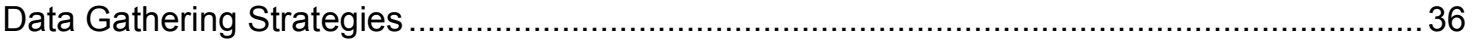

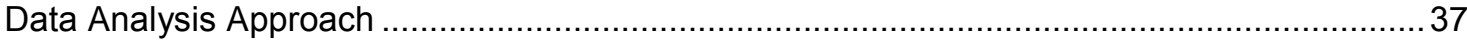

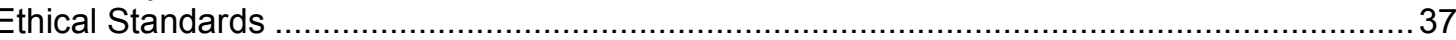

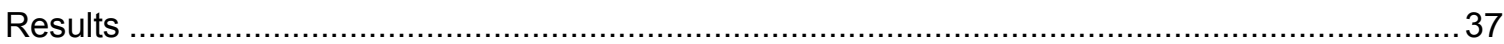

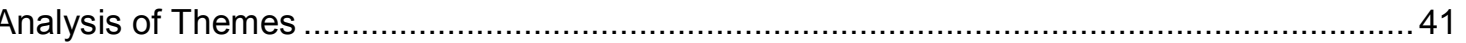

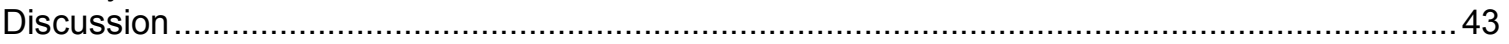

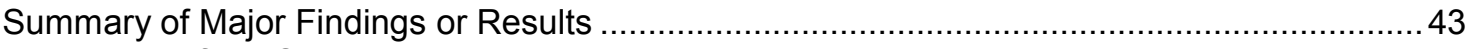

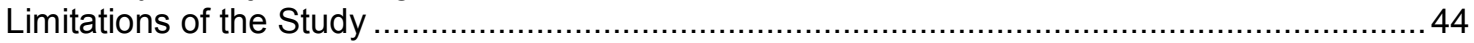

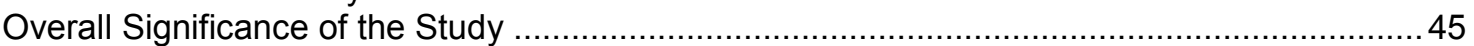

Implications for Future Research ............................................................................. 5

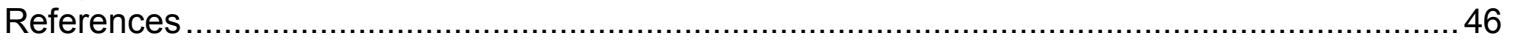

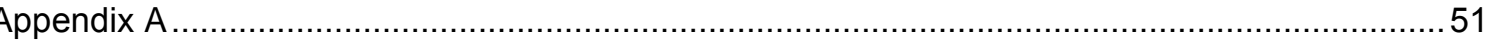

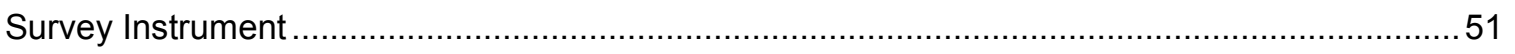

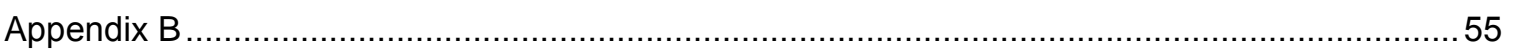

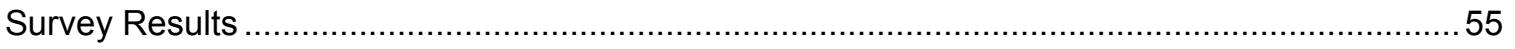

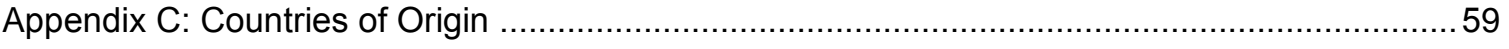

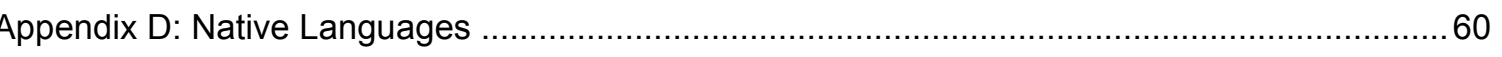

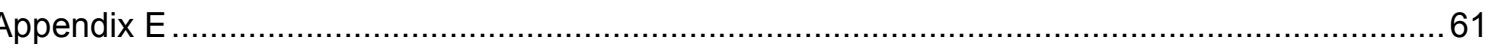

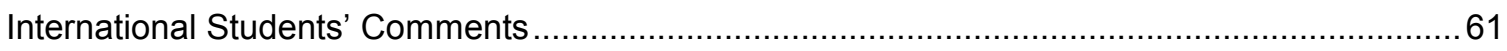

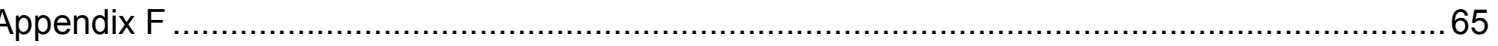

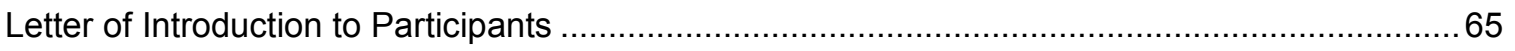

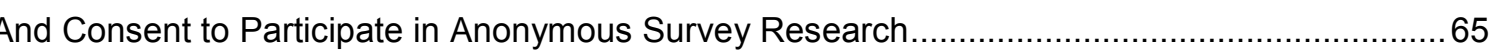


International students attending universities in the United States encounter academic, cultural, social, personal, and environmental difficulties, many of $\square$ hich stem from insufficient mastery of the $\square$ nglish language. The purpose of this study as to survey the academic needs of international students at Dominican University of California and compare the reported needs of these students $\square$ ith those of the larger population of international students.

$\square$ f the 55 surveys distributed, $3 \square \square$ ere returned. Survey results sho $\square$ ed that a large percentage of international students attending Dominican University of California $\square$ ere able to understand class lectures and $\square$ ritten materials and could finish their $\square$ or $\square$ in a timely manner. More challenging to international students $\square$ ere $\square$ riting essays and spea $\square$ ing in the classroom.

$\square$ large percentage of students reported that they did not utilize campus resources at the university. Language proficiency $\square$ as positively related to cultural adaptation, social integration, and academic progress. Social integration and cultural adaptation directly and positively correlated to academic success. The difficulties that $\square$ ere reported by international students at Dominican University of California $\square$ ere similar to those reported by international students at colleges and universities throughout the United States. It can thus be assumed that the components of successful international programs used at other institutions of higher learning $\square$ ill be applicable and useful at Dominican. From this data, a staff development model for faculty in service $\square$ ill be developed in the near future. 
Introduction

\section{Statement of Problem}

$\square$ ccording to Schoorman (2000), people in the United States lac $\square$ global awareness. This lack of awareness is problematic in light of our country's gro $\square$ ing need to ac $\square$ no $\square$ ledge our international interdependence, global technological interconnections, increasing global trade, and the call to participate in the resolution of global problems. Therefore, in order to be successful in international relationships people in the United States need to create a global partnership $\square$ ith foreign countries. The internationalization of higher education in the United States is an important aspect of this global partnership.

Dominican University of California (DUC) recognizes the need to internationalize its campus and has done much to realize this goal. To $\square$ ard this end, the university strives to recognize the needs of this population. There are many academic, social/cultural, personal/psychological and environmental challenges faced by international students on the Dominican campus. The Dominican University community $\square$ ants international students to be successful in their courses of study, thereby becoming ambassadors of $\square$ no $\square$ ledge and prosperity. Through these efforts, DUC also hopes to attract an increasing number of international students to the campus.

\section{Purpose Statement}

The needs of international students have been $\square$ idely researched. The purpose of this study is to identify the needs of international students on this 
campus, and ascertain the degree of similarity bet $\square$ een Dominican students and international students across the United States. From this data, the plan is to create a staff development model for faculty in service in this area. The focus of this research addresses the academic needs of this population and to ac $\square$ no $\square$ ledge the cultural, emotional, personal, and environmental needs as they relate to academic success.

\section{Hypotheses}

If in general the needs of international students are similar throughout the United States, then the needs of international students at DUC are similar to the larger population. Therefore, the $\square$ ays in $\square$ hich other universities have addressed these needs may be useful as a basis for faculty education on this campus. Conceptual Explanation

It can be assumed that DUC $\square$ ants to attract international students, $\square$ ho ill be successful in demonstrating academic competence to earn a diploma. It is assumed that the university community $\square$ ants to foster intercultural communication and understanding for international students, for $\square$ merican students, and for all faculty and staff.

\section{Literature Revie $\square$}

In $1 \square 5 \square$, President $\mathrm{D} \square$ ight $\mathrm{D}$. $\square$ isenho $\square$ er said, "The exchange of students...should be vastly expanded. Information and education are powerful forces in support of peace. ust as $\square$ ar begins in the minds of men, so does peace." (NAFSA, 2002, p. 2) Nineteen years later, President Jimmy Carter 
echoed this same sentiment when he said, "Only by knowing and understanding each other's experiences can we find common ground on which we can examine and resolve our differences...As the world becomes more and more interdependent, such mutual understanding becomes increasingly vital."

$(\mathrm{N} \square \mathrm{FS} \square, 2002$, p. 1)

Four reasons have been given in support of the need for the internationalization of higher education: $\square$ orld peace $\llbracket$ success in international competition $\square$ global $\square$ no $\square$ ledge $\square$ and global cooperation. $T \square$ o concerns underlie these four rationales: the international interdependence of the United States, and the lack of global awareness among its citizens. An educational institution's goals for internationalization are rooted in needs brought about by global technological interconnections, global trade, and the resolution of global problems such as pollution, hunger, disease, and terrorism (Schoorman, 2000).

A great asset to any country's efforts to internationalize its educational system is the utilization of its international students. Many international educators agree that international students are an important part of the effort (ibid.). The presence of these students on campuses allo $\square$ s opportunities for cultural and international understanding. International students, $\square$ hile here to achieve their o $\square$ n personal and academic goals, are al $\square$ ays cultural ambassadors (Sandhu $\square$ srabadi, $1 \square \square$ ). They can assume many roles, serving as educational resources in classroom discussion, counselors for study abroad, guest spea $\_$ers on cultural topics, and organizers of cross cultural events (Schoorman, 2000). 
During the 20002001 academic year, $5 \square \square, 6 \square$ international students studied in the United States. This accounts for appro $i$ imately 3. $\square$ percent of total enrollment in U.S. colleges and universities $\square$ ith these students contributing almost $\square 11.0 \square$ billion to the U.S. economy. The United States remains the leading destination for international students $\square$ ho $\square$ ever, there is gro $\square$ ing competition from $\square$ uropean countries aggressively courting these students. In 20002001 , the top ten countries of origin listed in order $\square$ ere China, India, aapan, Republic of $\square$ orea, Tai $\square$ an, Canada, Indonesia, Thailand, Tur $\sqsubset$ ey, and $\mathrm{Me}\lceil i c o(\mathrm{~N} \square \mathrm{FS} \square, 2002)$.

More than half of the international students $\square$ ho studied in $\square$ merica last year $\square$ ere from $\square$ sia. $\square$ bout $1 \square 0,000 \square$ ere from $\square$ ast $\square$ sia, $\square$ ith a third coming from China, representing the largest number of students from one country $\square$ ithin a three year period. $\square$ ppro $\square$ imately $\square 2,000$ international students came from Central $\square$ sia, primarily India, $\square$ hich sent $5 \square, 66 \square$ students last year. This $\square$ as a $2 \square$ percent increase from the preceding year. Nearly $\square, 000$ students came from $\mathrm{Pa} \square$ istan. $\square$ nly $\square 5$ students $\square$ ere from $\square$ fghanistan, $\square$ here the number of students studying in $\square$ merica has diminished over the last ten years (Manzo, 2001). In the United States, California and $\mathrm{Ne} \square \square$ or $\square$ led the nation in numbers of international students $\square$ ith $\square \square, 2 \square 1$ and $5 \square, 2 \square 6$ respectively. Te $\square$ as $\square$ as third $\square$ ith $3 \square, 35$ students. Seventy five percent of all international students bet $\square$ een 2000 and $2001 \square$ ere either self sponsored or fully funded by overseas sources (N $\square \mathrm{FS} \square$, 2002). 
$\square$ ppro $\square$ imately $\square 6$ percent of international students studying in the United States are undergraduates, 2 percent are graduates, and 5 percent are receiving practical training. The various fields of study of foreign students is as follo $\square$ s:

Field of Study

$\square$ usiness

$\square$ ngineering

Mathematics / Computer Science

Humanities

ducation

Social Sciences

Physical $\square$ Life Sciences

Fine or $\square$ pplied $\square$ rts

Liberal and General Studies

Health Professions

Intensive $\square$ nglish Language

$\square$ ther

\section{$\underline{\text { Percent of International Students }}$}

2

15

11

3

3

6

6

13

(McMurtrie, 2000)

Since September 11, 2001, $\square$ hen the $\square$ orld Trade Center To $\square$ ers in Ne $\square$ or $\square$ City $\square$ ere destroyed by a terrorist attac $\square$, education officials remain optimistic. Few international students have dropped out of United States' programs and immediate effects have been minimal. $\mathrm{Ho} \square$ ever, some e $\sqsubset$ change programs in the Middle $\square$ ast, South $\square$ sia, and Indonesia have been discontinued. Interest in $\square$ merican programs has declined. Some international students could not focus on their studies, and returned home as a result of parental an iety over their presence in on United States' soil (Manzo, 2001). 
Challenges and Stresses Faced by International Students in the United States

There are many academic, social/cultural, personal/psychological, and environmental challenges and stresses faced by international students. These are brought about by multiple factors: language barriers $\square$ brea $\square \mathrm{s} \square$ ith family and peer support systems (Sandhu $\square \square$ srabadi, $1 \square \square \square$ ) $\square$ differences in cultural values and assumptions and communication $\square$ and learning styles (Ladd $\square$ Ralph, $1 \square \square$ ) $\square$ as $\square$ ell as differences in psychological self constructs (Cross, $1 \square 5$ ). The process of adaptation of a student is also likely to be related to the "cultural distance" between the norms, values, and customs of the society of origin and those of the receiving society (Tatar $\square$ Horenczy $\square, 2000$ ).

Academic challenges. International students face many academic challenges $\square$ hen studying at colleges and universities in the United States. $\square$ ccording to $\mathrm{N} \square \mathrm{FS} \square$ : $\square$ ssociation of International $\square$ ducators (N $\square \mathrm{FS} \square$ ), proficiency in spo $\sqsubset$ en and $\square$ ritten $\square$ nglish is the greatest contributing factor to $\square$ ards the academic success of international students (Selvadurai, $1 \square \square 12$ ). $\neg$ et, the most common academic problems pertain to language difficulties (Nicholson, 2001). $\square$ hile many international students are able to pass a standardized proficiency e $\square$ amination in $\square$ nglish, they have difficulty functioning later in an academic setting. $\square$ ccording to $\mathrm{N} \square \mathrm{FS} \square$, standardized tests are useful indicators, but they should not be used as the main criteria in the selection of students for admission. In evaluating a foreign student's performance for admission to a college, the admission officer, the teachers in the $\square S L$ program, 
and the foreign student advisor must closely coordinate planning and decision ma $₫$ ing (Selvadurai, $1 \square \square 12$ ).

International students have difficulties in understanding lectures, e $\sqsubset$ pressing ideas, and $\square$ riting reports, and these problems have been largely attributed to a lac $\square$ of proficiency in $\square$ nglish (Nicholson, $2001 \square$ Selvadurai, $1 \square \square 1 \square$ 2). $\square$ ven though $\square 0$ percent of international students surveyed stated that they had significant difficulty $\square$ ith $\square$ nglish language usage, $\square 0$ percent stated they received no instruction in $\square$ nglish (Nicholson, 2001).

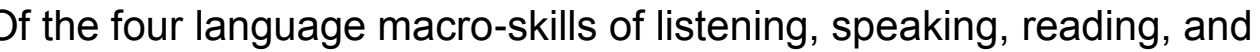
$\square$ riting, $\square$ riting is the s $\square$ ill that poses the most difficulty for international students. $\neg$ esides the challenge of $\square$ riting in grammatically correct $\square$ nglish, students often have difficulty e $\square$ pressing their ideas through $\square$ riting and speech, and at times give the impression that they do not have comple $i$ ity or depth to their thoughts ( $\square$ riguglio, 2000). $\square$ ne student $\mathrm{e} \square$ pressed his needs in this area in this $\square$ ay: $\square$ nd not just assistance $\square$ ith $\square \square$ riting, but e $\square$ pressing myself in intellectually mature language, in academic language. $\square$ ecause sometimes, that's what I think is a bit difficult for non English spea ing bac $₫$ ground people, to ma $\lceil$ e a distinction bet $\square$ een, for $\mathrm{e}\lceil$ ample, academic language, non academic language, and slang (student cited in $\square$ riguglio, 2000 , p. $\square$ 2 $)$.

Students often e $\llbracket$ press having problems reading te $\llbracket$ ts in $\square$ nglish, especially specialized te $t$ ts, stating that they find it time consuming and difficult (Nicholson, 2001). They fre $\square$ uently have problems reading $\square$ hat is $\square$ ritten on the blac $\square$ board 
in class. $\square$ ecause international students may have trouble listening to and understanding fast paced, e tended lectures, they also have difficulty ta $\square$ ing notes in class ( $\square$ riguglio, $2000 \square$ Par $₫ e r, 1 \square \square \square$ ).

Learning styles often play a role in difficulties encountered by international students. In 1990, Grasha put forward the definition of learning styles as, “...the preferences students have for thin $i n g$, relating to others, and particular types of classroom environments and experiences" (Ladd, 1999, p. 2). Cornett believed that students could adjust their learning styles according to the teaching style and the tas $\ulcorner\mathrm{s}$ before them. The most often $\sqsubset$ uoted definition of the term learning styles is by Keefe, who stated, "Learning styles are characteristic cognitive, affective, and psychological behaviors that serve as relatively stable indicators of how learners perceive, interact with, and respond to the learning environment" (Ladd, 1 $\square \square$, p. 2).

$\square$ ften, international students are slo $\square$ in adjusting their learning styles to the style of $\square$ merican education (Selvadurai, $1 \square \square 1$ ). They are often accustomed to participating in class and relating to their professors in $\square$ ays that may be very different from the $\square$ merican students in their classes. This can affect their ability to learn, to receive help, and to convey $\square$ no $\square$ ledge to the professor, all of $\square$ hich $\square$ ill negatively affect their learning e $\llbracket$ perience and academic progress ( $\square$ riguglio, 2000).

Furthermore, students are often shy about spea ing. Many feel their spo $\square$ en $\square$ nglish is not fluent enough for the demands of the classroom ( $\square$ riguglio, 2000). In technical, research oriented, or pedagogical courses, international 
students may lac $\square$ the vocabulary to phrase coherent $\square$ uestions or comments. $\square \mathrm{c} \square$ uiring ne $\square \square$ nglish $\square$ ords related to these areas re $\square$ uires e $\llbracket$ tended time and patience on the part of both the student and faculty (Par $\lceil e r, 1 \square \square \square)$.

Many international students are trained to listen to instructors rather than to spea $\square$ in class. In some cultures, instructors are seen as bearers of absolute truths and therefore should not be $\square$ uestioned. In the United States, students are invited to challenge their instructors and enter into debates. $\square$ ften the more casual classroom style can be disturbing. $\square$ hile $\square$ estern faculty student relationships are based on e $\leftarrow$ pectations of mutual honesty and respect, many international students have a respect for authority far beyond their $\square$ merican peers, $\square$ hich does not carry $\square$ ith it e $\square$ pectations of e $\square$ pressed reciprocation (Selvadurai, $1 \square \square 12$ ).

Research has found that learning styles differ in international students depending on country of origin. These differences have their roots in the self $\square$ constructs of the individual student and are derived from cultural beliefs, values, and the institutions that mold the structure and content of the self (Cross, $1 \square 5$ ). Though $\square$ sian students may have serious problems understanding lectures, ta $\square$ ing notes, ans $\square$ ering $\square$ uestions, and $\square$ riting essays, they prevent themselves from see $\square$ ing help as part of their psychological dispositions (Ladd, $1 \square \square$ ). Shyness and passivity in the classroom, as $\square$ ell as a preference to $\square$ ards collectivism rather than individualism, often interfere with students' willingness to independently reach out. Students may feel that putting their individual needs above the class needs or standing apart from the group in re $\sqsubset$ uiring personal 
attention in class, is inappropriate (Cross, $1 \square 5$ ). They may also feel that it is shameful to as $\square$ for help from the professor and that they should be able to succeed independently (Ladd, $1 \square \square$ ). Students may e $\square$ uate not $\square$ no $\square$ ing an ans $\square$ er $\square$ ith losing face and being humiliated. They may be afraid to loo $\square$ inept in front of the teacher or peers, especially $\square$ ith feelings of inade $\square$ uacy in using a second language ( $\square$ easley $\square$ Pearson, $1 \square \square \square$ ). Ho $\square$ ever, international students have also been found to prefer to receive instruction through listening and to cultivate close relationships $\square$ ith their professors (Ladd, $1 \square \square \square$ ).

Moreover, international students are often unaccustomed to fre $\sqsubset$ uent testing and may have more e e $\leftarrow$ perience ta $\_$ing essay type e $\_$aminations. The $\square$ uic $\square$ thin $\square$ ing re $\square$ uire by multiple choice and short ans $\square$ er e $\square$ ams may create psychological barriers and tension among students. In some countries, final grades are based only on the final $\mathrm{e}\lceil\mathrm{am} \square$ ho $\square$ ever, in the United States, course grades are based on $\square$ or $\square$ done throughout the semester. Tas $\square$ oriented students may be confused in settings $\square$ here the process is valued as much as the actual product and class participation is a large part of the evaluation process ( $\square$ alas, $2000 \llbracket$ Selvadurai, $1 \square \square \square$ 2).

$\square$ nother factor in academic learning is cross cultural $\square$ riting and thin $\square$ ing styles. Students in the United States are e $\square$ pected to present their arguments in the $\square$ nglish tradition of the strictly linear, logical development of ideas. $\square$ ccording to $\square$ easley $\square$ Pearson, (1 $\square \square \square$ ):

ssays are supposed to have an introduction $\square$ hich defines terms, the scope, focus, and theme of the thesis, as $\square$ ell as an outline of the 
structure or main points to be covered. The body develops in full the points outlined in the introduction (with a minimum of "irrelevancies") and the essay is rounded off $\square$ ith a conclusion that briefly summarizes the main points and theme of the essay (p.306).

The different $\square$ riting styles bet $\square$ een cultures involve different ideas of the responsibilities of the $\square$ riter and reader. Chinese, $\square$ orean, and $\llbracket$ apanese cultures place a much greater responsibility on the reader to interpret the message that the $\square$ riter may only imply, yet not logically state in a linear manner. In addition, there are different patterns of ordering and structuring the $\square$ ritten information presented ( $\square$ easley $\square$ Pearson, $1 \square \square \square$ ).

estern tradition places much emphasis on comparing, discussing, and evaluating arguments, and students are e $\llbracket$ pected to $\mathrm{e}\lceil$ press vie $\square$ points rather than simply duplicating an authoritative opinion. To $\square$ uote Mc $\square$ vedy, an academic from the University of Melbourne ( $\square$ easley $\square$ Pearson, $1 \square \square \square$ ):

...one of the most important qualities needed by a student to succeed is an ability to thin $\square$ logically and to develop a theme in a logical $\square$ ay $\square$ ith provision of appropriate "continuity". A student fluent in English but who lac $\ulcorner$ s the insight and ability to do this could $\square$ ell struggle to obtain a degree so that I must rate fluency in $\square$ nglish as less important than having a logical mind and the ability to appraise critically $\square$ hat is read or taught. $\square$ f course, if $\square$ nglish e $\llbracket$ pression is too poor to permit the student to state sufficiently clearly $\square$ hat he/she means, or to get do $\square$ n on paper sufficient 
information $\square$ ithin a given time, chances of success in study are also poor. (p. 306)

Critical analysis is expected in United States' universities. However, this change in behavior can be very difficult for students $\square$ ho have been educated to practice rote learning and memorization, and $\square$ ho seldom $\sqsubset$ uestion the teacher or information presented. In many countries, each subject of study at a university may have only one te $\downarrow t$ and only offer one point of vie $\square$ to the student ( $\square$ easley Pearson, $1 \square \square \square$, personal communication, 2000). Ho $\square$ ever, many educational researchers feel that this is an outdated stereotype and challenge this vie $\square$ point ( $\square$ easley $\square$ Pearson, $1 \square \square \square$ ).

Factors such as course structure, content, and academic standards can all be impediments to the academic goals of international students in the United States (Selvadurai, 1 $\square \square 12$ 2). Instructional techni $\square$ ues such as discovery learning may seem inappropriate, foreign, and inefficient $\square$ ays of learning (Par $\lceil e r, 1 \square \square \square$ ). $\square$ ther factors of the $\square$ estern educational system that international students have identified as problematic are home $\square$ or $\square$ grading differences, and teachers $\square$ ho are perceived as rude, $\square$ ho do not ta $\ulcorner$ e e $\square$ tra time $\square$ ith students, and $\square$ ho may use $\square$ hat students feel is inappropriate or vulgar language.

Studies have sho $\square \mathrm{n}$ a $\square$ ide range of responses from professors concerning their understanding of international students. Some professors feel that they $\square$ no $\square \square$ ell the needs of these students and try to accommodate student learning styles and language difficulties. $\square$ thers respond that they are relatively una $\square$ are of these needs, or feel that the students should be molded to an 
$\neg$ merican learning style. Therefore the professors do not ma $\_$e changes in the classrooms to accommodate these students. Some faculty observed that international students did not integrate $\square$ ith $\square$ merican students, and incorrectly assumed this behavior $\square$ as by choice. Ho $\square$ ever, the students have stated that they do $\square$ ish to integrate but need assistance from faculty $\square$ ithin the classroom setting (Trice, 2001).

Social/cultural \& personal/psychological challenges. International students are regarded as a population psychologically at ris $\square$ The results of most studies have sho $\square \mathrm{n}$ that integration of international students is highly correlated $\square$ ith positive outcomes, and marginalization contributes to, or reflects, poor psychological adjustment (Tartar $\square$ Horenczy $\square$ 2000). There is also a positive correlation bet $\square$ een social alienation and po $\square$ erlessness, meaninglessness, and normlessness (Nicholson, 2001). $\square$ study of international students from more than 50 different countries found that students reported higher than normal problems in the areas of an $i$ iety, depression, psychosomatic symptoms, and paranoia. In a longitudinal study of Tai $\square$ anese students studying in the United States, more than half reported a decline in emotional $\square$ ell being. $\square$ recent study sho $\square$ ed significant emotional distress in $\sqsubset$ apanese e $\llbracket$ change students as long as 6 months after returning from a 1 year $e \leftarrow$ perience studying in a foreign country. The present body of $\square$ no $\square$ ledge regarding psychological adaptation of international students suggests an e $\llbracket$ perience of significant acculturative stress (Tatar $\square$ Horenczy $\square, 2000$ ). 
Stressors that play major roles in mental health crises of international students include the follo $\square$ ing: culture shoc $\square$ e $\lceil$ pressed through an $\square$ iety, depression, hostility, tension, frustration, an $\sqsubset$ iety, anger, and stress $\llbracket$ societal e $\llbracket$ pectation for high academic performance $\square$ changes in social and economic status e $\sqsubset$ pressed through feelings of resentment and loss $\ulcorner$ and feelings of discrimination, alienation, and isolation (Nicholson 2000 Tatar $\square$ Horenczy $\square$ 2001). $\square$ ccording to Sandhu $\square \square$ srabadi (1 $\square \square \square$ ), homesic $\square$ ness, loneliness, fear, and pessimism are also major concerns.

Language difficulties, $\square$ hile playing a major role in academic problems, also contribute to personal and social problems. $\square$ eing understood is associated $\square$ ith feelings of acceptance and appreciation. Confusion, frustration, depression, and lo $\square$ self $e$ esteem are the results of not being understood. Language difficulties may lead international students to see $\square$ relationships $\square$ ith those $\square$ ho spea $\square$ their first language, thus hampering integration into $\square$ merican social groups (Nicholson, 2001). $\square$ merican students may be complacent $\square$ ith their situation and not feel the need to go out of their $\square$ ay to socialize $\square$ ith foreign students (Sandhu srabadi, $1 \square \square \square)$.

$\square$ ften international students are una $\square$ are of cultural differences in friendship building and dating eti $\square$ uette, along $\square$ ith other $\square$ mericans customs related to food habits, religious beliefs, and nonverbal communication. (Selvadurai, $1 \square \square$ ). Issues regarding body language and physical contact may strongly affect international students. $\square$ hile students from Latin $\square$ merican countries may regard hugging as a common $\square$ ay to communicate, students from 
other countries such as India may feel that such physical contact is e tremely intrusive ( $\square$ ibart, 2000).

$\square$ lac $\square$ of integration into $\square$ merican social groups may occur because many students have come from a collectivist culture $\square$ here individuals belong to a fe $\square$ stable in groups and have intense relationships $\square$ ithin those in groups. This is different from $\square$ mericans, $\square$ ho tend to belong to many in groups $\square$ ith less intense attachments and social obligations. $\square$ n international student $\square$ ho is more interdependent than an $\square$ merican student may perceive the $\square$ merican student as superficial and untrust $\square$ orthy (Cross, $1 \square 5$ ). The result is often a sense of po $\square$ erlessness, meaninglessness, and social estrangement, leading to alienation (Sandhu $\square \square$ srabadi, $1 \square \square \square$ ).

International students $\square$ ho are more interdependent than independent may see $\square$ to fit into $\square$ merican social groups by changing their behavior and attitudes, rather than e $\_$pecting others to change. This can lead to guilt and a feeling of betraying one's native cultural and familial values. It can place students in a double bind situation, caught bet $\square$ een the old values of their native land that they deeply respect, and the ne $\square$ values of the host culture that they feel they must embrace in order to succeed. This may also undermine personal identity and self respect. $\square$ Il this leads to acculturative stress (Sandhu $\square \square$ srabadi, $1 \square \square \square$ ). Components of Successful International Programs at Post-Secondary Institutions

General re $\square$ uirements for serving international students have been put forth in the Handboo $\square$ of $\square$ ccreditation (2001). In summary, these guidelines re $\sqsubset$ uire that the educational institution must demonstrate service to international 
students in a legally and ethically responsible, unbiased, and sensitive manner ( $\square$ ccrediting Commission for Senior Colleges and Universities, 2001). The $\square$ ssociation of International $\square$ ducation $\square$ dministrators ( $\square \square \square$ ) also offers guidelines for international education at U.S. colleges and universities. These guidelines specify that there should $\mathrm{e}$ ist a professional staff that can provide the re $\sqsubset$ uired support services for international students (Schoorman, 2000). $\square$ ccording to $\mathrm{N} \square \mathrm{FS} \square$ (2001), programs of international education ta $\ulcorner$ e many forms and are located at colleges and universities $\square$ ith different purposes, sizes, and settings. Regardless of these differences, it is only $\square$ hen an educational institution ma es a conscious commitment of resources to its international program that the program $\square$ ill be successful. Underlying such commitment are the follo $\square$ ing institutional principles put for $\square$ ard by N $\square \mathrm{FS} \square$ presented here is summary:

1. The institution should have a clearly stated policy, endorsed by the governing board, $\square$ hich includes goals and objectives of the international student program developed by the institution. The policy should include planning and budget considerations. Personnel and resources $\not$ both administrative and academic $\square$ should be sufficient to assure that the program can be operated in $\square$ ays that are consistent $\square$ ith the principles put forth in the document.

2. The e ecutive staff of the institution should discuss $\square$ ith the faculty and administrative staff the implications of the international program policy for the academic programs and staff. 
3. Programs should be closely related to and consistent $\square$ ith the purposes and strengths of the institution.

$\square$ Regardless of program size, the institution should ac $\square$ no $\square$ ledge its responsibility to demonstrate sensitivity to cultural needs - social, religious, dietary, and housing. These must be accounted for in the planning and e $\leftarrow$ ecution of the program.

5. Services should be performed by personnel $\square$ ho are trained for their particular responsibilities. Faculty and staff should receive appropriate training for the activities they manage.

6. Staff and faculty should develop and maintain respect and sensitivity to $\square$ ards those of different cultures.

$\neg$ The institution should periodically evaluate programs, policies, and services, and program goals.

The admissions process. $\square$ ny international program begins $\square$ ith the recruitment and admission of students. $\mathrm{N} \square \mathrm{FS} \square$ (2002) has put forth principles of good practice for these processes. The goal of the international admissions process is to identify, attract, and admit $\square$ ualified students $\square$ hose educational goals fit $\square$ ell $\square$ ith the mission and offering of the recruiting institution. Staff $\square$ or $\square$ ing to $\square$ ard the admission of international students should have specialized $\lceil$ no $\square$ ledge, s $\mathbf{i l l s}$, and resources, and professional judgment.

The admissions office should have a strong commitment to student service and development, a clear understanding of the institution's mission, policies, and standards, an ability to clearly communicate $\square$ ith prospective 
international students and recruits, and conduct outreach in an ethical manner. The admissions office should understand the processes and re $\sqsubset$ uirements of the immigration regulating branches of the U.S. government and responsibly manage record $\lceil$ eeping according to accepted professional standards. The department must also consider the differences in document issuing practices around the $\square$ orld and evaluate documentation accurately and fairly, $\square$ hile effectively coordinating its efforts $\square$ ith other offices involved in the admissions process for international students (N $\square \mathrm{FS} \square, 2002$ ).

International student services. $\square$ s stated in $\mathrm{N} \square \mathrm{FS} \square$ documentation (2001), it is the responsibility of the host institution to meet the needs of its international students in an organized, directed, and funded manner. Regardless of the number of international students present on campus, the college or university is re $\sim$ uired to offer a basic level of support that enables the student, once accepted into the institution, to be successful. The follo $\square$ ing $N \square F S \square$ principles support these services.

1. The host institution should clearly state its intentions to provide special support services to international students. These services should include advisement and counseling, mandated and technical services in compliance $\square$ ith U.S. government regulations, and coordination and liaison $\square$ ith the community. 2. There must be one unit in the host institution responsible for coordinating these services $\square$ ith clear and ac $\square$ no $\square$ ledged designation of responsibility for these services. This must occur regardless of the number of international students present at the institution or level of funding. 
3. $\square$ orientation program should be in place that introduces students to the physical environment, registration procedures, academic policies, housing, counseling and health services, visa re $\square$ uirements and INS regulations, and financial matters. Social and intercultural activities should be offered. $\square$ dvising services should be provided on an ongoing basis $\square$ ith respect to personal counseling, emergency needs, and preparation for departure and reentry to home countries.

$\square$ The staff should maintain high ethical and professional standards.

Educator. $\mathrm{N} \square \mathrm{FS} \square$ (2001) also has many guidelines for international educators. $\square$ mong them are:

1. $\square$ no $\square$ ledge of the cultural adjustment process.

2. Counseling and advising s $₫ i l l s$.

3. $\square \square$ areness of ho $\square$ culture and language influence learning styles.

․ $\square$ no $\square$ ledge of learning another language, educational systems other than those in the U.S, and cultural values and assumptions and their effect on interactions $\square$ ith individuals and groups.

5. Intercultural communication s $\mathrm{s}$ ills

$\mathrm{N} \square \mathrm{FS} \square$ provides grants to colleges and universities, $\square$ hose staff and faculty develop model programs to support international students. Final reports about these programs can be obtained free of charge for use at other institutions. amples of such program topics are as follo $\square$ s. In the area of international student $\mathbf{s} \sqsubset$ ill development topics include Promoting Student Leadership Development and Home Country Reentry/Transitional Issues for International 
Students. In the area of culture shoc $\square$ and helping international students understand $\square$ merica topics include Intercultural Field Trips/ $\square$ ploring the Local Landscapes $\square$ Understanding U.S. Culture and Diversity (including Religious Diversity, Holiday Traditions, and Native $\square$ merican Issues) $\square$ Understanding U.S History, Politics, and the $\square$ udicial System $\square$ Promoting Cross Gender Understanding and Gender Specific Issues $\square \square$ ppreciating U.S. $\square$ rt and $\square$ ntertainment $\square$ and Media and Contemporary Issues. In the area of International Students $\square$ djustment program topics include $\square$ rientation/Peer Mentoring of International Students, Cross Cultural Communication Issues and $\square$ or shops, and International/ $\square$ merican Student Roommate Issues (N $\square \mathrm{FS} \square, 1 \square \square \square$ ).

Successful components of student service. Services to international students are best coordinated through an International Student Services office. Services should include pre arrival information and assistance, orientation activities, ongoing advisory services, advocacy and intervention, and the development of programs that enhance interaction bet $\square$ een students and members of the academic community. Pre arrival information can be organized in a variety of $\square$ ays. Programs or information on a variety of topics pertaining to life in the United Stated can be offered by agencies such as governmental, private institutions, or alumni groups in the home country, or by the United States institution, using a variety of multilingual media. This includes printed information pac $\sqsubset$ ets, brochures, videos, $t \square$ enty four hour message systems, electronic mail, and the $\square$ orld $\square$ ide $\square$ eb. Current trends in international student admissions sho $\square$ a predominance of $\square$ sians, those from affluent bac $\square$ grounds, and more 
men than $\square$ omen, suggesting that efforts should be made to recruit a broader demographic of international student (Schoorman, 2000).

$\neg$ rientation for international students is one of the most common forms of international student services offered by colleges and universities. It typically includes immigration information, an introduction to university re $\sqsubset$ uirements and services, and an introduction to the community, focusing on cross cultural differences. $\square$ n academic and discipline $\$ specific orientation $\square$ ith the participation of faculty members is strongly recommended (Schoorman, 2000). Summer bridge programs have been created $\square$ here international students come for the summer prior to their first semester at the university and engage in activities that focus on cultural adjustment as $\square$ ell as academic and language s $\square$ ills ( $\square$ ezar, 2000). $\square$ ee $\lessdot$ end orientation retreats designed for international students have also been found to be more effective than single day orientations $\square$ here all ne $\square$ students are addressed (N $\square \mathrm{FS} \square, 1 \square \square)$.

$\square$ ngoing advising services uni $\square$ ue to international students include immigration advising, cross cultural counseling, social and cultural adaptation, and preparation for departure and return. Counseling services should be designed to help alleviate culture shoc $\square$ and home sic $\square$ ness, and promote understanding of cultural differences bet $\square$ een the social norms of their home country and the U.S., and adaptation to the U.S. educational. $\square$ ngoing advising services uni $\sqsubset$ ue to international students include immigration advising, cross $\square$ cultural counseling, social and cultural adaptation, and preparation for departure and return. Counseling services should be designed to help alleviate culture 
shoc $\square$ and homesic $\llbracket$ ness, and to promote understanding of cultural differences bet $\square$ een the social norms of their home country and the U.S., and adaptation to the U.S. educational system. $\square$ ther services that should be offered to international students are tutoring, mentoring, and health services (Schoorman, 2000).

$\square$ important component of an international program is a comprehensive section of the university $\square$ eb site for international students. Students can do $\square$ nload vital information $\square$ hile still in their country of origin to better prepare themselves for their ne $\square$ intercultural university e $\square$ perience. Three e $\varangle$ cellent e $\sqsubset$ amples can be found on the $\square$ eb sites of the University of San Francisco ( $\square \square \square$.usfa.edu), $\square$ eliot College( $\square \square \square$.beliot.edu), and Montclair State University ( $\square \square \square$.montclair.edu). $\square$ comprehensive student handboo $\square$ designed specifically for international students is also useful and often can be do $\square$ nloaded from the eb site.

Successful academic components. Several international educators have indicated that faculty members are the most crucial players in the process of successful internationalization of a university, and therefore, of the success of its international students. Many faculty members $\square$ ho have e $\square$ pertise in this area are underutilized. Most $\square$ ill need to develop e $\square$ pertise, and several strategies have been suggested. These include $\square$ or $\square$ shops on international issues, incentives such as release time and stipends for curriculum development, the study of a foreign language and culture, and opportunities to teach abroad and for involvement in e $\downarrow$ tra curricular international activities. $\square$ oth faculty and staff must 
become globally literate and cross culturally sensitive. Professional development or $\backsim$ shops, attendance at national and international conferences, and the active recruitment of internationally oriented personnel are all important (Schoorman, 2000).

International students can help to educate faculty, staff, students, and the surrounding community. These students must be given opportunities to serve as educational resources in classroom discussions, as peer and study abroad counselors, as guest spea $\lceil$ ers on cultural topics, and as organizers of cross $\square$ cultural events (Schoorman, 2000). This $\square$ ill help lead faculty, staff, and students to intercultural adaptability, including listening s $\square$ ills and the ability to interpret behavior and apply social or e $\lceil$ periential learning in different cultural conte $t s$ ( $\square$ eszotars $₫$, 2001).

The classroom environment is the main arena in $\square$ hich the international student's needs must be recognized. There is a need for clear and comprehensive instructions about academic assignments $\square$ ith timely diagnostic feedbac $\square$. During lectures, the e $₫$ tended use of overhead transparencies, and printed lecture notes or lecture outlines are helpful to international students. Professors should spea $\square$ slo $\square$ ly and clearly, $\square$ ithout the use of slang, and $\square$ rite clearly on the board. Students benefit from teaching styles that incorporate practical e $\_$amples to illustrate theoretical concepts and use modeling and coaching of metacognitive strategies ( $\square$ easley $\square$ Pearson, $1 \square \square \square \square$ riguglio, 2000). $\square$ ngoing curriculum development at some universities has transformed courses from traditional teacher directed courses involving lectures and tutorial in $\square$ hich 
students are relatively passive. Changes produced shorter but more fre $\sqsubset$ uent lectures, $\square$ ith either more fre $\sqsubset$ uent meeting times or e $\downarrow$ tended class times that progressed at a slo $\square$ er pace. $\square$ or $\square$ shop type formats that allo $\square$ the student to be a more active and self directed learner are being incorporated at many schools ( $\square$ alas, $2000 \square$ Par $\llbracket$ er, $1 \square \square \square$ ). Groups designed to increase cultural mi $\square$ ing, serve to undermine the tendency to self segregation. More presentation may be re $\sim$ uired of students (Trice, 2001). Field trips incorporated into curricula enhance cultural and historical understanding (N $\square \mathrm{FS} \square, 1 \square \square$ ). $\square$ learner support program utilizing both faculty and peers is also effective ( $\square$ easley $\square$ Pearson, $1 \square \square \square$ ). For those courses in $\square$ hich class participation is factored into the final grade, some professors allo $\square$ good participation to enhance student performance but do not lo $\square$ er the grade if class participation is infre $\square$ uent ( $\square$ alas, 2000).

Ladd and Ruby (1 $\square \square$ ) suggest that since many foreign students are used to class lecture $\square$ ith minimal participation, the instructor can begin to slo $\square$ ly introduce open ended $\sqsubset$ uestions that re $\sqsubset$ uire opinion, problem solving, and decision ma $\square$ ing. If these concepts are introduced immediately, international students may be uncomfortable and fearful. The instructor should build the students' self confidence and trust. "Thinking on your feet" exercises such as uestions regarding simple self description to describing an object and progressing to hypothetical $\sqsubset$ uestions the student must ans $\square$ er, can be used. In addition, offering students tips in class on ho $\square$ to study or utilize a certain ne $\square$ learning style is helpful. Instructors should also be careful $\square$ hen using idioms that the student may ta $\_$literally instead of figuratively. For e $\ulcorner$ample, the phrase, 
"quite a few..." may mean simply "few" to the student instead of "many" (Ladd \& Ruby, $1 \square \square$ ). It has been recommended that at the beginning of the term, instructors should also meet $\square$ ith international students after class, specifically to discuss methods of teaching, e $\lceil$ pectations, and class rules. $\square$ ccording to Ladd and Ruby, "The classroom is not a place to play the game of 'let's see if the students can figure out the rules'; it is a place where cognitive and affective gro $\square$ th can—and should—flourish" (1999, p. 6).

$\square$ utside of the classroom, academic assistance and support can be offered through tutorials and tutoring sessions, seminars on communication and study s $\square$ ills, and one to one consultation and support, all geared to $\square$ ard the international student's unique needs (Briguglio, 2000). In general, a broad dialogue bet $\square$ een international students, faculty, and native students is very important. Informal discussions, in $\square$ hich international students e $\llbracket$ press their academic e $\llbracket$ pectations and concerns, could be valuable ( $\square$ alas, 2000 ).

$\square$ hen communication difficulties arise, it is usually more comple $\square$ than just language problems because language is intert $\square$ ined $\square$ ith culture. Therefore, $\square$ hen intercultural communication ta $\_$es place, it is important for all parties to ta $\sqsubset e$ into account differences in past e $\llbracket$ periences, behavioral norms, beliefs, and body language (Trice, 2001).

Successful cultural/personal/psychological components. Researchers agree on three functional aspects of social support. These are emotional support involving intimacy, concern, and attachment $\square$ instrumental support, involving 
provision of assistance $\lceil$ and informational support, involving the provision of information or guidance relevant to the situation (Tartar $\square$ Horenczy $\square, 2000$ ).

Developmental educators, educational psychologists, and sociologists agree that peer group interactions form a significant bonding that shapes students' social and academic integration as well as their institutional commitment. Students $\square$ ho are personally satisfied through forming strong partnerships $\square$ ith peers and institutional staff and teaching faculty, and $\square$ ho participate in school and community related activities, have a high retention rate. Positive e $\square$ periences and e $\llbracket$ pectations $\square$ ithin a peer group are associated $\square$ ith high academic performance. Institutional programs that facilitate the formation of connections $\square$ ith an individual student, a group, or an institution as a $\square$ hole may improve the international student's experience of and persistence at the university, regardless of the demography of the student (I egulu, $1 \square \square$ ).

$\square$ ithin the academic setting, faculty can assign a diverse group of students to a study team as a $\square$ ay of encouraging international students to spea $\square$ out and avoid culture shoc $\square$ (Reingold, $1 \square \square$ ). The internationalization of social/cultural events on campus is an important aspect of an international campus. T $\square$ o successful outcomes $\square$ ill be that students of all cultures feel $\square$ elcome and positive intercultural communication and intermingling becomes the norm. $\square$ ll administrators, faculty, and students $\square$ ould be $a \square$ are and appreciative of the cultural diversity of the campus and actively become involved in facilitating cross cultural interaction. Faculty and staff can as $\square$ international students affiliated $\square$ ith their departments $\square$ hat events $\square$ ould most interest them. The 
students can be dra $\square \mathrm{n}$ into the planning of these events. If students are uncomfortable participating $\square$ ith the large groups, smaller events can be planned specifically for them (Trice, 2001).

$\square$ ther events can involve the entire campus community, not just a specific department. Some e $\ulcorner$ amples of these types of events are the formation of student organizations, international food fairs, dances, plays, film festivals, music recitals, and poetry readings. Cross cultural forums on a variety of international and personal topics can be organized as $\square$ ell as $\square$ ee $\square$ end retreats (N $\square \mathrm{FS} \square$, $1 \square \square$ ). These events are often organized by the students themselves (Schoorman, 2000).

Residence halls can facilitate cross cultural integration through residential arrangements. It is generally found best to place international students in the same room $\square$ ith a student $\square$ hose first language is $\square$ nglish. Residence halls can facilitate guest spea $\ulcorner$ ers on international issues, sho $\square$ films, provide discussion sessions, and create a buddy system and/or peer advisor program that supports cross cultural transitions and friendships, and helps the student to solve many other academic and practical problems (Reingold, $1 \square \square$ Schoorman, 2000). It has been sho $\square \mathrm{n}$ that peer programs can have a significant positive effect on the adjustment of international students (Nicholson, 2001). Residence assistants should be culturally educated and sensitive. Culturally appropriate meals should be offered in the dining halls if possible (Schoorman, 2000).

Henderson, et al. (as put forth in Nicholson, 2001) offered nine recommendations to international students to help them manage culture shoc $\square$ 
They are: (1) $\square$ e mentally prepared. The student must be sympathetic and non $\square$ judgmental to $\square$ ards other cultures. (2) $\square$ e culturally prepared. The student should prepare at home by learning as much as possible about the host country and ho $\square$ living conditions there might differ from those at home. (3) $\square$ e linguistically prepared. International students need to learn as much about the host language as possible to reduce failures and feelings of helplessness. ( $\square) \square$ e involved $\square$ ith hosts. Students should socialize $\square$ ith people of the host culture since this $\square$ ill lead to fe $\square$ er adjustment problems than those $\square$ ho remain isolated from their hosts. (5) $\square$ e creative and e $\square$ perimental. International students must be $\square$ illing to e $\llbracket$ pose themselves to many types of people and ideas. (6). $\square$ e culturally sensitive. Sojourners need to be $\mathrm{a} \square$ are of customs and traditions of the host country. ( $\square$ ) $\square$ e patient and fle $\square$ ible. In a ne $\square$ environment, the sojourner must be $\square$ illing to be inconvenienced and $\square$ ait for ans $\square$ ers that may ta $\ulcorner$ e time. ( $\square$ ) $\square$ e realistic in e $\llbracket$ pectations. ( $\square) \square$ ccept the challenge of intercultural $\mathrm{e} \llbracket$ periences. This $\square$ ill aid personal gro $\square$ th and allo $\square \mathrm{e} \llbracket$ periences to be more fulfilling (Nicholson, 2001).

International students should also be encouraged to participate in cultural activities to develop leadership s $₫ i l l s$. $\square$ amples are participation in student government organizations, campus media, student counseling, and resident hall advising. This allo $\square$ s the student to be $e \sqcap$ posed to the needs of all students and help to problem solve using a variety of cultural perspectives (Schoorman, 2000). 
Suggestions from International Students

International students have suggestions that they feel $\square$ ill help them succeed at U.S. post $/$ secondary institutions. The follo $\square$ ing is a list of these suggestions and summaries of student comments (Nicholson, 2001).

1. Class size should be small. This allo $\square$ s for more opportunity to e $\square$ press oneself to the professor and to tal $\square$ easily $\square$ ith other students in discussion groups. In large groups, students spea $\square \square$ uic $\square$ ly to allo $\square$ for more students to participate. Smaller classes allo $\square$ for a rela $\_$ed atmosphere.

2. Students should be invited to social events such as potluc $\square$ dinners.

3. $\square$ merican students should help in finding research articles, provide transportation, and help in other $\square$ ays $\square$ ithout being as $\sqsubset$ ed. They should be friendly, tal $\square$ to international students, invite them to their homes for dinner, and offer housing during times $\square$ hen students cannot live in the dormitories. They should allow the students to visit the American student's friends and relatives in other places $\square$ hen they travel.

․ Professors should ta $e$ time to listen to international students and to sho an understanding of their cultures in class discussions.

5. Professors should have more office hours.

6. $\square$ tra tutoring hours should be offered.

․ Professors should spea $\square$ slo $\square$ ly in class, use simpler vocabulary, print or use good hand $\square$ riting on the board, and distribute handouts of their lecture notes. 
$\square$ Professors should eep promises, invite international students to dinner, and develop relationships $\square$ ith them.

$\square . T$ The $\square$ ffice of International Student Services should operate in the follo $\square$ ing $\square$ ays. It should help but not control the students, help $\square$ ith employment problems, provide a counseling center only for international students to deal $\square$ ith homesic $\square$ ness and interpersonal relations, ma $\sqsubset$ e available a place to stay $\square$ hen students arrive, and notify the student beforehand about transportation to campus from the airport. The office should e $\ulcorner$ ercise its authority $\square$ hen addressing academic problems and provide support for international students in communicating their problems to various departments.

\section{Summary}

International students are a valued part of the educational system in the United States, bringing $\square$ ith them a belief in the universal values of education, cultural diversity, and good $\square$ ill. The difficulties faced by international students have not changed much since the early part of the $20^{\text {th }}$ century, even though the number of students has gro $\square \mathrm{n}$ and the diversity of countries of origin has e $\lceil$ panded. The primary difficulty for international students remains language. $\square$ ven $\square$ ith the ability to pass an $\square$ nglish proficiency e $\llbracket$ am, once a student must function academically and socially using $\square$ nglish, many difficulties arise.

Post secondary educational institutions that invite international students to their campuses must provide appropriate academic, cultural, and personal support for the student. This support is usually coordinated through the 
International Student Services Department staffed by $\square$ ualified and trained staff. All aspects of the student's life can be addressed through this office.

In classes, faculty should demonstrate cultural understanding and accommodate the student such that the classroom e $\llbracket$ perience is both positive and challenging. Course curriculum must be compatible with the international student's learning style, or else instruction in adjustment to the United States' system of education must be provided. Tutoring and peer mentoring can provide support outside of the classroom.

Social support on campus can come from many campus community members including staff, faculty, and fello $\square$ students, both international and U.S. Course curriculum, cultural forums and events, and social occasions can all assist the international student in adjusting to life in a ne $\square$ country $\square$ ith the added benefit that the campus community as a $\square$ hole can become more internationally $\mathrm{a} \square$ are.

This international a $\square$ areness is vital to our nation and the $\square$ orld as a $\neg$ hole. Prosperity, health, and peace are no longer determined by each nation but are dependent on all nations honoring the humanity in all beings. This can be brought about or enhanced by intercultural understanding in the conte $t$ of higher $\square$ no $\square$ ledge, ideals, and hope, realized as change. Therefore, international students must remain a vital part of the United States' system of higher education. Through this means, intercultural understanding may have a chance to flourish faster than the seeds of fear, doubt, and resentment can gro $\square$ ithin the seemingly separate populations of the $\square$ orld. 


\section{Methods and Procedures}

\section{Sample and Site}

The sample population includes international students enrolled in graduate and undergraduate classes at Dominican University of California. $\square$ ppro $\square$ imately 55 students form the sample. The site was this researcher's office at Dominican. $\square$ lso, many students preferred to complete the survey in their homes and return them later.

\section{Access and Permissions}

Dr. $\square$ es $\square$ oung, Director of the $\square$ ffice of International Student Services has given his permission to conduct this study. Dr. $\square$ en Porada, Provost, has been informed of the study.

\section{Data Gathering Strategies}

The original strategy $\square$ as to meet privately or in small groups $\square$ ith international students at Dominican so that the survey could be e $\llbracket$ plained to the students. Some students did this, but many preferred to ta $\_$their surveys home and return them later. Students completed the survey $\sqsubset$ uestions and some also added personal comments. Some students mailed their surveys, some e mailed them, and some completed them $\square$ hile this researcher $\square$ aited to assist them. $\square$ n attempt $\square$ as made to contact all international students at Dominican via e mail, postal mail, and phone calls. The student list used $\square$ as not completely accurate. Some students on the list $\square$ ere actually not attending, much of the contact information $\square$ as incorrect, and some students $\square$ ho $\square$ ere attending $\square$ ere not on the original list and $\square$ ere added later. 


\section{Data Analysis Approach}

This $\square$ uasi $[$ e perimental survey includes both $\square$ ualitative and $\square$ uantitative information. Simple percentages have been used to analyze Li $\lessdot$ ert scale (interval) results.

\section{Ethical Standards}

This study adheres to the guidelines for human subject research in accord $\square$ ith the $\square$ merican Psychological $\square$ ssociation ( $\square \mathrm{P} \square, 2001$ ) ethical standards. $\square$ lso, this study $\square$ as revie $\square$ ed and approved by the Institutional Revie $\square \square$ oard for Protection of Human Subjects.

\section{Results}

$\square$ f the 55 surveys distributed, $3 \square \square$ ere returned. $\square \| l$ surveys $\square$ ere used. The usable return rate $\square$ as $6 \square \square$. $\square \|$ respondents $\square$ ere international students attending Dominican University of California.

Part $\square$ of the survey addressed demographic information. Some information was not completed due to the respondent's desire to remain anonymous. Fifty four percent of respondents $\square$ ere $\square$ omen, $\square 2 \square \square$ ere men, and

did not identify their gender. The respondents ranged in age from $1 \square$ years to $2 \square$ years ( $\mathrm{M} \square 23$ years). The average length of time spent in the United States $\square$ as $1 \square .5$ months and the average length of time at Dominican $\square$ as $1 \square$ months. The length of time spea $\square$ ing $\square$ nglish ranged $\square$ idely from 2 months to 15 years. Thirty percent of the respondents $\square$ ere graduate students, $5 \square \square \square$ ere undergraduates of $\square$ hich $2 \square \square \square$ ere freshman, and $11 \square$ did not respond to this $\square$ uestion. Si $\not y$ eight percent of respondents $\square$ ere from $\square$ sia, $1 \square \square \square$ ere from a 
$\square$ ide range of countries in the $\square$ mericas, $\square$ urope, and $\square$ frica, and $13 \square$ gave no data. For a list of countries of origin and native languages, see appendices $C$ and $D$ respectively.

Part $\square$ of the survey addressed the $\square$ nglish language proficiency of international students. Concerning the question, "How would you rate your $\square$ nglish proficiency in the follo $\square$ ing?" four areas were addressed:

listening/understanding, spea $\square$ ing, reading, and $\square$ riting. In the category of listening/understanding, $60 \square$ rated themselves as either $\mathrm{e} \sqsubset$ cellent (22 $\square$ ) or very

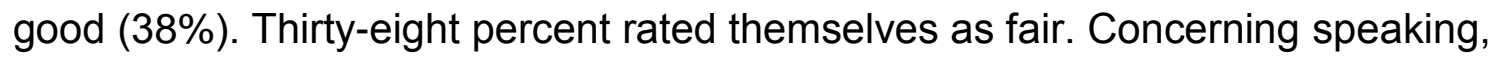
$\square \square$ rated themselves as either e $\square$ cellent (16 $\square$ ) or very good (2 $\square \square$ ). Ho $\square$ ever, $5 \square \square$ rated themselves as either fair $(\square 3 \square)$ or poor $(1 \square \square)$. In the area of reading, $\square \square$ responded that they $\square$ ere e $\sqsubset$ cellent or very good $\square$ hile $3 \square \square$ rated themselves as fair. $\square$ riting s sills $\square$ ere lo $\square$ est, $\square$ ith $6 \square \square$ of the respondents rating themselves as either fair or poor.

Part $\square-\square$ NGLISH L $\square$ NGU $\square$ G $\square \square \square \mathrm{C} \square$ GR $\square$ UND $\square$ ow woul $\square$ you rate your $\square$ n $\square$ lish proficiency in the followin

\begin{tabular}{|l|l|l|l|l|l|}
\hline & $\square($ cellent & $\square$ ery Good & Fair & Poor & Un $\square$ no $\square$ n \\
\hline $\begin{array}{l}\text { Listening/ } \\
\text { understanding }\end{array}$ & $\square(22 \square)$ & $1 \square(3 \square \square)$ & $1 \square(3 \square \square)$ & 0 & $1(3 \square)$ \\
\hline Spea $\square$ ing & $6(16 \square)$ & $\square(2 \square \square)$ & $16(\square \square)$ & $5(1 \square \square)$ & $1(3 \square)$ \\
\hline Reading & $\square(22 \square)$ & $1 \square(3 \square \square)$ & $1 \square(3 \square \square)$ & 0 & $1(3 \square)$ \\
\hline$\square$ riting & $3(\square \square)$ & $\square(2 \square \square)$ & $22(5 \square \square)$ & $2(5 \square)$ & $1(3 \square)$ \\
\hline
\end{tabular}

Part C of the international student survey $\square$ as composed of $\square 0 \square$ uestions. These questions addressed academic skills applied to the following: students' classroom participation $\square$ relationships $\square$ ith faculty and peers $\square$ ability to understand and complete assignments and e $\ulcorner$ ams $\square$ and recourse to academic support services. $\square$ ll results can be found in $\square$ ppendi $\square \square$. 
Seventy five percent of all students surveyed responded that they understood most of $\square$ hat their professors said in class lectures. Ho $\square$ ever, $16 \square$ felt that professors spo $\ulcorner$ e too $\square$ uic $\square$ y $\square$ hen lecturing. Seventy $\llbracket$ nine percent of students surveyed responded that they could understand their professors $\square$ hen they spo $\square$ e personally. $\square$ verall, listening s $\square i l l s ~ \square$ ere good and responses $\square$ ere consistent.

Seventy three percent of students responded that they understood most of $\square$ hat $\square$ as $\square$ ritten in their te $\square$ tboo $\square$ s, $\square$ ith $\square \square \square$ stating they understood $\square$ hat $\square$ as $\square$ ritten on the $\square$ hite board in class. It should be noted that $\square \square \square$ of respondents reported that they understood typed handouts the professors gave them. Si ty $\square$ seven percent felt they $\square$ ere able to finish reading assignments on time. Si $₫$ teen percent felt they could not. $\square$ verall, reading s $\square$ ills $\square$ ere good and responses $\square$ ere consistent.

Regarding $\square$ riting s $₫ i l l s, \square \square \square$ of respondents stated they $\square$ ere able to finish $\square$ riting assignments on time. Ho $\square$ ever, students reported having difficulty $\square$ ith various $\square$ riting tas $\square$ s. Thirty seven percent had difficulty ta $\square$ ing notes in class in $\square$ nglish, and $3 \square \square$ stated they had difficulty $\square$ riting essays, $\square$ ith $\square 2 \square$ being uncertain. $\square$ ight respondents (21 $\square$ ) felt they did not have difficulty $\square$ riting essays. $\square$ uestions regarding spea $\square$ ing s $\square$ ills $\square$ ere related to interaction $\square$ ith professors and students in class as $\square$ ell as out of class. $\square$ nly $3 \square \square$ of students stated they $\square$ ere not afraid to spea $\square$ in class and $\square$ ere not afraid of ma $\square$ ing mista $\square$ es $\square$ hen spea $\square$ ing. Thirty seven percent of respondents stated they $\square$ ere afraid they $\square$ ould be perceived as stupid if they as $\sqsubset$ ed $\sqsubset$ uestions in class and 
agreed $\square$ ith the statement that they could not e $\lceil$ press their true thoughts in spo $\sqsubset$ en $\square$ nglish. $T \square$ enty one percent $\square$ ere afraid to as $\square \square$ uestions of their classmates for fear they $\square$ ould be thought stupid. $\square$ f the students $\square$ ho $\square$ ere afraid of spea $\square$ ing up in class, only 3 respondents felt it $\square$ as rude to as $\square$ $\square$ uestions. Ho $\square$ ever, $2 \square \square$ felt it $\square$ as rude to disagree $\square$ ith the professor and 3 $\square$ of respondents $\square$ ere uncertain.

The last area of consideration $\square$ as resources international students utilized for help. $\square$ hile $65 \square$ stated they as $\ulcorner$ ed their classmates for help, $\square \square$ stated they as $\lceil$ ed only international students from their home region for help and support. Thirty four percent of students did not feel comfortable participating in study groups $\square$ ith other students, $\square$ ith $1 \square \square$ being uncertain. Thirty four percent of students stated they sought help through academic support services (tutoring), and $2 \square \square$ stated they made fre $\square$ uent use of academic support services. $\square$ hile $6 \square \square$ of international students felt their professors respected them, only $55 \square$ felt their professors $\square$ anted to help them, and only $\square 5 \square$ felt the professors $\square$ ere $\square$ illing to spend e tra time helping them. $\square$ nly $\square \square \square$ felt that their academic advisor $\square$ as $\square$ illing to spend e tra time helping them.

Fifty three percent of international students stated that they as $\llbracket$ ed their professors for help. $\square$ nly $2 \square \square$ stated that their professors understood their personal and academic challenges, $\square$ hile $53 \square$ felt their academic advisor understood these challenges. Si ty one percent of international students $\square$ anted their professors to $\square$ no $\square$ more about their culture and $50 \square \square$ anted professors to include more about their culture and e $\llbracket$ perience in class. 
International Students $\square 1$

\section{Analysis of Themes}

The areas of strength for the international student population participating in this survey are listening and understanding spo $\sqsubset$ en $\square$ nglish and reading and understanding $\square$ ritten $\square$ nglish. Spea $\square$ ing and $\square$ riting in $\square$ nglish are areas needing more support. One student wrote, "I have no problems in reading and understanding but $\square$ hen it comes to $\square$ rite in $\square$ nglish and spea $\square$ up in class, it is difficult." Other reasons for difficulties in spea $\square$ ing in class are e $\lfloor$ plained in the follo $\square$ ing $\square$ uotes from three different respondents:

I understand all of study materials because of the dictionary. It's impossible to survive as an international students $\square$ ithout it $\square$ In $\square$ apan, $\square$ e don't have much presentation and discussion compare to here. Therefore, it's hard to speak up in the class, even though I have class in Japan.

It is tough to spea $\square$ up in front of the class especially because I am shy. I am afraid to ma $\ulcorner$ e mista $\ulcorner$ es and my pronunciation. $\square$ hen it comes to $\square$ rite, I usually ta $\square$ e longer than my normal to remember the right $\square$ ords that express what I really want to say on the essays. My essays don't $\square$ uite e $\square$ press $\square$ hat I $\square$ ant to say.

It's hard to participate in a discussion in the class, and also I sometimes feel so sorry for other students since I ta $\lceil$ e a time to say even a short comment. I feel like l'm stealing and wasting their time.

Difficulties in these areas lead to a lac $\square$ of cultural understanding 
and utilization of assistance from faculty and students $\square$ ho are not from international students' home countries. A large percentage of international students have difficulty participating verbally in class. This is based on their fear of rejection from others because of poor language $\mathbf{s} \leftarrow$ ills.

Si ty nine percent of international students either did not feel that their professors understood them or they $\square$ ere unsure. They $\square$ ere unclear about the level of interest their professors had in giving them e $₫$ tra assistance. $\square$ ne student stated, "I think DU's most professors are still unaware of the difference between American students \& foreign students." Therefore, a large percentage of students did not as $\square$ their professors for help. The students felt that their academic advisors $\square$ ere slightly more understanding of their needs but $\square$ ere not significantly more available than the professors.

International students made moderate use of academic support services and less than a third made use of these services fre $\square$ uently. Some students $\square$ rote comments on their surveys re $\square$ uesting tutoring services, $\square$ hich seemed to indicate that the students $\square$ ere not $a \square$ are that these services $\square$ ere already available to them. There $\square$ as a positive correlation bet $\square$ een strong language $\mathbf{s}$ ¿ills and feelings that professors understood and cared for the students. There $\square$ as also a positive relationship bet $\square$ een language $\mathbf{s} \square$ $\amalg l s$ and class participation, as well as the student's ability to interact inside and outside the classroom with students from other countries.

Patterns similar to those of other colleges and universities $\square$ ere found at Dominican. Language proficiency $\square$ as positively correlated to cultural adaptation, 
social integration, and academic progress. Social integration and cultural adaptation also directly and positively correlated to academic success. The difficulties that $\square$ ere reported by international students at Dominican University of California are therefore similar to those reported by international students at colleges and universities throughout the United States. It can thus be assumed that the components of successful international programs used at other institutions of higher learning $\square$ ill be applicable and useful at Dominican University of California.

\section{Discussion}

\section{Summary of Major Findings or Results}

In general, the majority of international students attending Dominican University of California $\square$ ere able to understand class lectures and $\square$ ritten materials and could finish their $\square$ or $\square$ in a timely manner. Students understood $\square$ ritten handouts given in class, $\square$ hich supplemented lectures.

International students identified $\square$ riting assignments and spea $\square$ ing in the classroom as special challenges. Many international students had difficulty participating in class discussion or as $\square$ ing $\square$ uestions, and most did not enter into debate $\square$ ith the professor in class. Students $\square$ ere afraid of being perceived as stupid. $\square$ hen as $\square$ ing for help, many international students sought out those from their native country and did not ma $\ulcorner$ e full use of fello $\square$ classmates, professors, or advisors. $\square$ hile most students $\square$ ere not confident about their $\square$ riting s sills, less than half of those students sought support through tutoring. 
International students at Dominican University of California need further assistance from faculty, staff, and other students. Communication is the $\sqsubset$ ey issue. International students need to $\square$ no $\square$ that faculty and staff are available to them and are interested in learning about their cultures. There is a need to develop and clearly define resources for international students.

\section{Limitations of the Study}

$\square$ ppro $\square$ imately $31 \square$ of international students attending Dominican did not complete the survey. There may be differing reasons for this. $\square$ ne student, $\square$ ho chose not to complete the survey, said he/she $\square$ as afraid of retribution because $\square$ hat he/she had to say $\square$ as critical and $\square$ ould also allo $\square$ for easy identification of the student. There may have been other students $\square$ ho $\square$ ere also afraid to fill out the survey. Several students $\square$ ho did complete the survey needed to be assured that they $\square$ ould not be penalized for their responses. Therefore, this survey may have been completed primarily by students $\square$ ho already felt a certain level of trust and $\square$ ho had accomplished a significant level of cultural adaptation and academic success. Had all international students completed the survey, the results may have sho $\square$ n greater difficulties in language proficiency, academics, and social bonding.

$\square$ nother limitation of the study is that the survey $\square$ as a self report.

Students' self [reports of their s $\mathbf{i}$ ills may vary from what a faculty member's evaluation of the students may be. This could be due to various factors such as lac $\square$ of objectivity, or personal or national pride. It is common for international students to feel pressure to achieve academic e $\varangle$ cellence. 


\section{Overall Significance of the Study}

Dominican University of California is committed to providing international students an e $\varangle$ cellent education. The university $\square$ ishes to recruit an increasing number of international students to its campus and therefore see $\llbracket \mathrm{s}$ to e $\llbracket$ pand and improve resources for these students. Understanding the needs of international students is the first step in reaching these goals. This researcher $\square$ ill use the results of this study to create a staff development model for faculty and staff in service. $\square$ reas to be developed $\square$ ill include facilitation of communication and cultural understanding, as $\square$ ell as strategies and tools to support academic progress. Secondarily, supportive strategies relative to personal/psychological and social/cultural integration $\square$ ill be discussed.

Implications for Future Research

This research study focused on the academic needs of international students at Dominican University of California. It did not focus on the personal/ psychological, environmental, or social/cultural needs of this population. $\square$ ecause it has been sho $\square \mathrm{n}$ that these factors greatly influence academic e $\square$ cellence, and because Dominican see $\ulcorner s$ to establish itself as an international university of the highest order, further research in these areas $\square$ ould be beneficial to all. 


\section{References}

ccrediting Commission for Senior Colleges and Universities. (2001). Handbook of Accreditation - Standards- Addressing Core Commitments to Institutional Capacity and Educational Effectiveness-Institutional Review Process - Policies and Practices. $\square$ lameda, C $\square$ : $\square$ estern $\square$ ssociation of Schools and Colleges

$(\square \square S C)$.

$\square$ merican Psychological $\square$ ssociation. (2001). Publication Manual of the American Psychological Association. $\square$ ashington, DC: $\square$ merican Psychological ssociation.

־alas, A. (2000). Using participation to assess students' knowledge. [Electronic version $\square$ College Teaching, 48(๑), 12 .

$\neg$ easley, C. $\square \square$ Pearson, C. $\square$. L. (1 $\square \square)$. Facilitating the learning of transitional students: Strategies for success for all students. Wlectronic version. Higher Education Research \& Development, 18(3), 30321.

$\square$ riguglio, C. (2000). Language and cultural issues for $\square$ nglish $a$ as $a$ Second/Foreign Language students in transnational educational settings. Higher Education in Europe, XXV(3), $₫ 25233$.

Cross, S. $\square$. (1 $\square 5)$. Self construals, coping, and stress in cross cultural adaptation. Journal of Cross-Cultural Psychology, 26(6), $6 \llbracket 3 \square$. 


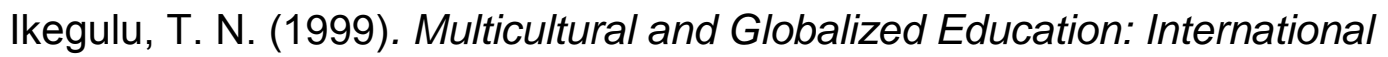
Students' Perspective. Reports $\square$ Research No.1 $₫$. Department of $\square$ ducational Leadership, College of $\square$ ducation, Grambling State University. $\square$ ducational Leadership, College of $\square$ ducation, Grambling State University.

$\neg$ ezar, $\square$. (2000). Summer bridge programs: Supporting all students.

$\square$ lectronic version $\square$ ERIC Digest. $\square$ RIC Clearinghouse on Higher $\square$ ducation, $\square$ ashington, D.C. $\square \square \square 1566 \square$.

Ladd, P. Ruby, R. (1 $\square \square \square$ ). Learning style and adjustment issues of international students. $\square$ lectronic version $\square$ Journal of Education for Business, 74(6) $1 \square$ 10.

Manzo, $\square$. $\square$. (2001). Global reach of local colleges $\lessdot$ eeps gro $\square$ ing. $\square$ lectronic version $\square$ Community College Week, 14(10), 16.

McMurtrie, $\square$. (2000). Foreign students at U.S. institution, $1 \square \square \square 2000$. $\square$ lectronic version $\square$ Chronicle of Higher Education, 47(12), 16.

$\mathrm{N} \square \mathrm{FS} \square(1 \square \square \square$ ). Cooperative Grants Program - Model Program List. Retrieved une 20, 2002, from http:// $\square \square \square$.nafsa.org/coop.

$\mathrm{N} \square \mathrm{FS} \square$ (2002). Cooperative Grants Program - Model Program List. Retrieved une 20, 2002, from http:// $\square \square \square$.nafsa.org/coop. 
$\mathrm{N} \square \mathrm{FS} \square$ (2002). Important Data on International Education Exchange To and From the United States. Retrieved $\square$ une $\square, 2002$, from http:// $\square \square \square$.nafsa.org/content/PublicPolicy/Dataon/nternational $\square$ ducation/F actSheet.htm.

$\mathrm{N} \square \mathrm{FS} \square$ (2001). NAFSA's Principles for Institutions. Retrieved May 2 $\square, 2002$ from http:// $\square \square \square$.nafsa.org/content/InsideN $\square \mathrm{FS} \square / \square$ thicsandStandards/Principles Institutions.htm.

$\mathrm{N} \square \mathrm{FS} \square$ (2001). NAFSA's Principles for International Student and Scholar Services.

Retrieved May 2দ, 2002 from http:// $\square \square \square$. nafsa.org/concent/InsideN $\square \mathrm{FS} \square / \square$ thicsandStandards/Principls ScholarServices.htm.

$\mathrm{N} \square \mathrm{FS} \square$ (2002). NAFSA's Principles of Good Practice for the Recruitment and Admission of International Students. Retrieved May 2দ, 2002 from http:// $\square \square \square$.nafsa.org/contentN $\square \mathrm{FS} \square / \square$ thicsandStandards/Principles $\square \mathrm{DS} \square$ C.htm.

$\mathrm{N} \square \mathrm{FS} \square,(1 \square 6)$. Statement of Professional Competencies for International Educators. Retrieved May 2দ, 2002 from http:// $\square \square \square$.nafsa.org/content/InsideN $\square \mathrm{FS} \square / \square$ thicsandstandards/Statement PC.htm. 
$\mathrm{N} \square \mathrm{FS} \square$ (2002). The U.S. Presidents on Fulbright and International $\square$ change Programs. Retrieved $\sqsubset$ une $\square, 2002$, from http:// $\square \square \square$.nafsa.org/content/ $\square$ boutInternational $\square$ ducation/Resources/ Presidents. htm.

Nicholson, M. $\square$. (2001). Adaptation of Asian students to American culture. (Reports - Research No. 1凸3) Indiana University South $\square$ end.

Par $\lessdot$ er, D.R. (1 $\square \square)$. Teaching, learning, and working with international students: A case study. (Paper presented at the $\square$ nnual meeting of the Mid South

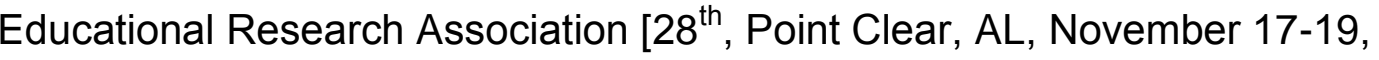
$1 \square \square($ ). (Reports - Research No. 1〔3.) Louisiana Tech University. Reingold, $\square(1 \square \square \square$. The melting pot still has a fe $\square$ lumps. Business Week, $3600,10 \square$

Sandhu, D.S. $\square$ srabadi, $\square$. R. (1 $\square \square$ ). Development of an acculturative stress scale for international students: Preliminary finding. 四lectronic version $\$$ Psychological Reports, 75, $₫ 35 \square \square \square$.

Schoorman, D. (2000). How is internationalization implemented? A framework for organizational practice. (Information $\square$ nalysis No. $0 \square 0$ ). Florida $\square$ tlantic University, Department of Teacher $\square$ ducation.

Selvadurai, R. (1 $\square \square$ ). Problems faced by international students in $\square$ merican Colleges and universities. $\square$ lectronic version $\square$ Community Review, 12(1/2), 16. 
Tatar, M $\sqcap$ Horenczy $\square$ G. (2000). Counseling students on the move: The effects of culture of origin and permanence of relocation among international college students. $\square$ lectronic version $\square$ Journal of College Counseling, 3(1), 115.

Trice, $\square$. G. (2001). Faculty Perceptions of Graduate International Students: The Benefits and Challenges. ( $\square$ valuative report $\square 1 \square$ ). Purdue University, Department of $\square$ ducational Studies.

$\sqsubset$ eszotars $\square$, P. (2001). $\square$ RIC revie $\square$ : Issues in global education initiatives in the community college. 四lectronic version Community College Review, 29(1), 111.

$\square$ ibart, R. (2000). $\square$ campus $\square$ here the $\square$ orld meets. $\square$ lectronic version $\square$ Christian Science Monitor, 93(3), 133. 
International Students 51

$\square$ ppendi $\square$

Survey Instrument 
Date:

\section{Part A - DEMOGRAPHICS:}

1. Gender: male female

3. Native country:

5. Length of time at DUC:

7. How long speaking English?

9. Class level:
2. Age in years:

4. Length of time in U.S:

6. First language:

8. What is your major?

10. Residence during the school year?

Part B - ENGLISH LANGUAGE BACKGROUND

How would you rate your English proficiency in the following?

\begin{tabular}{|l|l|l|l|l|}
\hline & Excellent & Very Good & Fair & Poor \\
\hline $\begin{array}{l}\text { Listening/ } \\
\text { understanding }\end{array}$ & & & & \\
\hline Speaking & & & & \\
\hline Reading & & & & \\
\hline Writing & & & & \\
\hline
\end{tabular}

\section{Any other comments about your English language proficiency?}

\section{Part C - ACADEMIC NEEDS}

The following are a series of statements regarding your academic life at Dominican University of California. Circle the response that best reflects your opinion, feelings, or practice:

$(\mathbf{S A}=$ strongly agree, $\mathbf{A}=$ agree, $\mathbf{U N}=$ uncertain, $\mathbf{D}=$ disagree, $\mathbf{S D}=$ strongly disagree

1. I understand most of what my professors are saying when lecturing in class.

SA A UN D SD

2. My professors speak too quickly when lecturing.

SA A UN D SD

3. I understand what my professors say when speaking to me personally.

SA A UN D SD

4. I understand most of what is written in my textbooks.

5. I am able to finish reading assignments on time.

SA A UN D SD

6. I understand what is written on the white board in class. 
7. I understand the typed handouts my professors give me.

8. I am able to finish writing assignments on time.

9. I seek tutoring to help me write my papers.

10. I have difficulty taking notes in class.

11. I take notes in English in class.

12. My learning style is compatible with my professors' teaching styles.

13. I have difficulty writing essays.

14. I have difficulty organizing my written work correctly.

15. I cannot express my true thoughts in written English.

16. I cannot express my true thoughts in spoken English.

17. I am afraid to speak up during class.

18. I am afraid of making mistakes when speaking in class.

19. I feel it is not appropriate to disagree with my professors.

20. I would like my professors to know more about my culture.

21. My professors should include more of my culture $\&$ experience in class.

22. My professors understand my personal and academic challenges.

23. My professors want to help me.

24. My professors are willing to spend extra time helping me.

25. My academic advisor understands my personal and academic challenges.

26. My academic advisor is willing to spend extra time helping me.

27. My professors show me respect.

28. My classroom is too informal.

29. I feel comfortable participating in study groups with other students.

30. I receive help from my fellow students.

31. I think there are too many tests given.

32. I am not used to taking multiple choice tests. I prefer essay exams.
SA A UN D SD

SA A UN D SD

SA A UN D SD

SA A UN D SD

SA A UN D SD

SA A UN D SD

SA A UN D SD

SA A UN D SD

SA A UN D SD

SA A UN D SD

SA A UN D SD

SA A UN D SD

SA A UN D SD

SA A UN D SD

SA A UN D SD

SA A UN D SD

SA A UN D SD

SA A UN D SD

SA A UN D SD

SA A UN D SD

SA A UN D SD

SA A UN D SD

SA A UN D SD

SA A UN D SD

SA A UN D SD

SA A UN D SD 
34. I feel it is rude to ask questions during class.

35. I am afraid people will think I am stupid if I ask questions in class.

36. I am afraid my classmates will think I am stupid if I ask them questions.

37. I ask my professors for help.

38. I ask my classmates for help.

39. I ask only international students from my home region for help and support.

40. I make frequent use of academic support services (tutoring).

If you would like to further explain any of your responses from the statements above, please do so here.

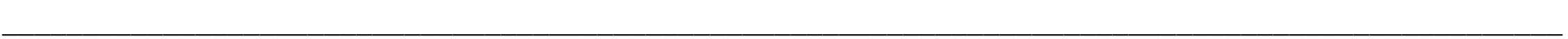

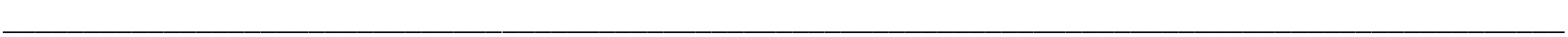

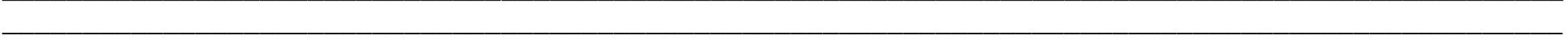

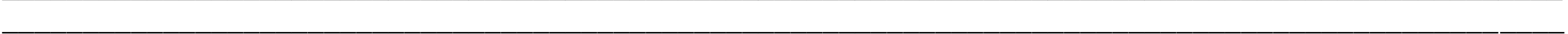

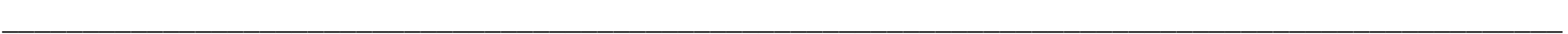

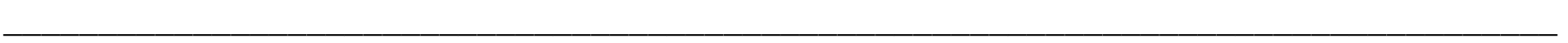

\section{Part D - OTHER GENERAL NEEDS/COMMENTS}

1. What else could the university do to support you academically?

2. Do you have any other comments about your linguistic or educational needs?
SA A UN D SD

SA A UN D SD

SA A UN D SD

SA A UN D SD

SA A UN D SD 
$\square$ ppendi $\square$

Survey Results 
Part A - DEMOGRAPHICS: Total \# of respondents: 38, Response rate : $69 \%$

$\square . \square$ en $\square$ er: male: 16 ( $\square \square$ ) female: $20(5 \square \square) \square$ un $\square$ no $\square$ n

$\square$. $\square$ ative countries: See appendi $\square \mathrm{C}$

$\square$ Len $\square$ th of time at $\mathbf{D} \square \square$ : average $\square 1 \square$ months

$\square . \square$ ow lon $\square$ speakin $\square \square$ n $\square$ lish: range $\square 2$ mo. to 15 yrs. $\square . \square$ e in years: range from $1 \square$ to $3 \square$ average: 23 years

$\square$ Len $\square$ th of time in $\square$.S: $\square$ verage $\square 1 \square .5$ months (1 $\square$ years)

$\square$. irst lan $\square$ ua $\square \mathbf{e}:$ See appendi $\square \mathrm{D}$

$\square . ~ \square$ lass level: graduate $\square 30 \square$ undergraduate $\square 5 \square \square$ freshman $\square 2 \square \square$ un $\square$ no $\square$ n: $11 \square$

\section{Part B - ENGLISH LANGUAGE BACKGROUND}

How would you rate your English proficiency in the following?

\begin{tabular}{|l|l|l|l|l|l|}
\hline & $\square$ cellent & $\square$ ery $\square$ oo $\square$ & $\square$ air & $\square$ oor & $\square$ nknown \\
\hline $\begin{array}{l}\text { Listening/ } \\
\text { understanding }\end{array}$ & $\mathbf{8}(\mathbf{2 2 \%})$ & $\mathbf{1 4}(\mathbf{3 8 \%})$ & $\mathbf{1 4}(\mathbf{3 8 \%})$ & $\mathbf{0}$ & $\mathbf{1 ( 3 \% )}$ \\
\hline Speaking & $\mathbf{6 ( 1 6 \% )}$ & $\mathbf{9 ( 2 4 \% )}$ & $16(\square \square)$ & $5(1 \square \square)$ & $\mathbf{1 ( 3 \% )}$ \\
\hline Reading & $\square(22 \square)$ & $\mathbf{1 4 ( 3 8 \% )}$ & $\mathbf{1 4}(\mathbf{3 8 \%})$ & 0 & $\mathbf{1 ( 3 \% )}$ \\
\hline Writing & $\mathbf{3 ( 8 \% )}$ & $\mathbf{2 2 ( 5 9 \% )}$ & $2(5 \square)$ & $\mathbf{1 ( 3 \% )}$ \\
\hline
\end{tabular}

$\square$ ny other comments about your $\square \mathbf{n} \square$ lish lan $\square$ ua $\square$ e proficiency $\square$ See appendi $\square \square$.

\section{Part C - ACADEMIC NEEDS}

The following are a series of statements regarding your academic life at Dominican University of California. Circle the response that best reflects your opinion, feelings, or practice:

(S $\square \square$ strongly agree, $\square \square$ agree, $\square \square \square$ uncertain, D $\square$ disagree, SD $\square$ strongly disagree $\square \square \square$ no response

\section{$\begin{array}{llllllllll}\text { SA } & \text { A } & \text { SA \& A } & \text { UN } & \text { D } & \text { SD } & \text { D \& SD } & \text { NR }\end{array}$}

1. I understand most of $\square$ hat my professors are saying $\square$ hen lecturing in class $11(29 \%) \quad 17$ (45\%) 27 (74\%)

2. My professors spea $\square$ too $\square$ uic $\square$ y $\square$ hen lecturing.

$0 \quad 6(16 \square)$

$7(18 \%) \quad 2(5 \%) \quad 0$

1

3. I understand $\square$ hat my professors say $\square$ hen spea $\square$ ing to me personally.

$14(37 \%) \quad 16(42 \%) \quad 30(79 \%)$

$13(35 \square) 12(32 \square) \quad 6(16 \square)$

$1 \square(\square \square) \quad 1$

$\square . \quad$ I understand most of $\square$ hat is $\square$ ritten in my te tboo $\square$ s.

$16(\square \square) \quad 12(32 \square) \quad 2 \square(\square 3 \square)$

$6(16 \%) \quad 1(3 \%) \quad 0$

$13(3 \square \square) \quad 12(32 \square) \quad 25(6 \square \square)$

$\square(21 \square) \quad 1(3 \square) \quad 0$

5. I am able to finish reading assignments on time.

6. I understand $\square$ hat is $\square$ ritten on the $\square$ hite board in class

$10(26 \square) 20(53 \square) \quad 30(\square \square \square)$

$6(16 \square) \quad \square(11 \square) \quad 2(5 \square)$

$6(16 \square) \quad 1$

. 
7. I understand the typed handouts my professors give me.

$\square . \quad$ I am able to finish $\square$ riting assignments on time.

$\square . \quad$ I see $\square$ tutoring to help me $\square$ rite my papers.

10. I have difficulty ta ing notes in class.

11. I ta $\_$notes in $\square$ nglish in class.

12. My learning style is compatible with my professors' teaching styles.

13. I have difficulty $\square$ riting essays.

1凸. I have difficulty organizing my $\square$ ritten $\square$ or $\square$ correctly.

15. I cannot e $\llbracket$ press my true thoughts in $\square$ ritten $\square$ nglish.

16. I cannot e press my true thoughts in spo $\underline{\text { en }} \square$ nglish.

$1 \sqsubset \mathrm{I}$ am afraid to spea $\square$ up during class.

1․ I am afraid of ma $\square$ ing mista $\square$ es $\square$ hen spea ing in class

$1 \square . \quad$ feel it is not appropriate to disagree $\square$ ith my professors.

20. I $\square$ ould li $\llbracket$ e my professors to $\square$ no $\square$ more about my culture.

21. My professors should include more of my culture $\square \mathrm{e}$ perience in class.

22. My professors understand my personal and academic challenges.

23. My professors $\square$ ant to help me.

$2 \sqsubset$ My professors are $\square$ illing to spend e $₫$ tra time helping me.

25. My academic advisor understands my personal and academic challenges.

26. My academic advisor is $\square$ illing to spend e tra time helping me.

$2 \square \quad$ My professors sho $\square$ me respect.

2匹. My classroom is too informal.

\section{$\underline{\text { SA }}$}

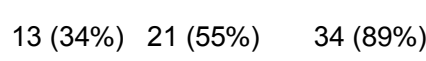

\begin{tabular}{|c|c|c|c|c|c|c|}
\hline $12(32 \square)$ & $22(5 \square \square)$ & $3 \square(\square \square)$ & $1(3 \square)$ & $2(5 \square)$ & 0 & \\
\hline $5(13 \square)$ & $\square(21 \square)$ & $13(3 \square \square)$ & $13(3 \square \square)$ & $6(16 \square)$ & $\square(11 \square)$ & $10(26 \square)$ \\
\hline $3(\square)$ & $11(2 \square \square)$ & $1 \square(3 \square \square)$ & $\square(21 \square)$ & $\square(21 \square)$ & $\square(1 \square \square)$ & $15(3 \square \square)$ \\
\hline $10(26 \square)$ & $1 \square(\square \square \square)$ & $2 \square(\square \square \square)$ & $\square(21 \square)$ & $1(3 \square)$ & 0 & \\
\hline $5(13 \square)$ & $\square(21 \square)$ & $13(3 \square \square)$ & $15(3 \square \square)$ & $\square(1 \square \square)$ & 0 & \\
\hline$\square(11 \square)$ & $\square(2 \square \square)$ & $13(3 \square \square)$ & $16(\square \square)$ & $\square(1 \square \square)$ & $1(3 \square)$ & $\square(21 \square)$ \\
\hline $5(13 \square)$ & $5(13 \square)$ & $10(26 \square)$ & $\square(2 \square \square)$ & $1 \square(3 \square \square)$ & $3(\square)$ & $1 \square(\square \square)$ \\
\hline $3(\square)$ & $10(26 \square)$ & $13(3 \square \square)$ & $\square(1 \square \square)$ & $12(32 \square)$ & $5(13 \square)$ & $1 \square(\square \square)$ \\
\hline $6(16 \square)$ & $\square(21 \square)$ & $1 \square(3 \square \square)$ & $6(16 \square)$ & $12(32 \square)$ & $5(13 \square)$ & $1 \square(\square \square)$ \\
\hline $6(16 \square)$ & $11(2 \square \square)$ & $1 \square(\square \square)$ & $\square(1 \square)$ & $6(16 \square)$ & $\square(1 \square)$ & $13(3 \square \square)$ \\
\hline $6(16 \square)$ & $12(32 \square)$ & $1 \square(\square \square \square)$ & $6(16 \square)$ & $10(26 \square)$ & $3(\square)$ & $13(3 \square \square)$ \\
\hline $1(3 \square)$ & $10(26 \square)$ & $11(2 \square \square)$ & $13(3 \square)$ & $6(16 \square)$ & $\square(1 \square \square)$ & $13(3 \square \square)$ \\
\hline$\square(21 \square)$ & $15(\square 0 \square)$ & $23(61 \square)$ & $\square(1 \square \square)$ & $5(13 \square)$ & $2(5 \square)$ & $\square(1 \square \square)$ \\
\hline $6(16 \square)$ & $13(3 \square \square)$ & $1 \square(50 \square)$ & $10(26 \square)$ & $\square(11 \square)$ & $\square(11 \square)$ & $\square(21 \square)$ \\
\hline $5(13 \square)$ & $6(16 \square)$ & $11(2 \square \square)$ & $15(\square \square)$ & $\square(2 \square \square)$ & $2(5 \square)$ & $11(2 \square \square)$ \\
\hline $5(13 \square)$ & $16(\llbracket \square)$ & $21(55 \square)$ & $11(2 \square)$ & $5(13 \square)$ & 0 & \\
\hline$\square(11 \square)$ & $13(3 \square \square)$ & $1 \square(\square \square)$ & $13(3 \square \square)$ & $5(13 \square)$ & $2(5 \square)$ & $6(16 \square)$ \\
\hline$\square(1 \square)$ & $13(3 \square \square)$ & $20(53 \square)$ & $11(2 \square \square)$ & $3(\square \square)$ & $3(\square \square)$ & $6(16 \square)$ \\
\hline $5(13 \square)$ & $13(3 \square \square)$ & $1 \square(\square \square \square)$ & $11(2 \square \square)$ & $6(16 \square)$ & $2(5 \square)$ & $\square(21 \square)$ \\
\hline$\square(2 \square \square)$ & $1 \square(\square 5 \square)$ & $26(6 \square \square)$ & $\square(1 \square \square)$ & $\square(11 \square)$ & 0 & \\
\hline 0 & $5(13 \square)$ & & $16(\square \square 1$ & $15(3 \square)$ & $1(3 \square)$ & $16(\square \square)$ \\
\hline
\end{tabular}


International Students

SA A SA \& A

$2 \llbracket \quad$ I feel comfortable participating in study groups $\square$ ith other students.

\begin{tabular}{|c|c|c|c|c|c|c|}
\hline$\square(11 \square)$ & $13(3 \square \square)$ & $1 \square(\square \square)$ & $\square(1 \square \square)$ & $12(32 \square)$ & $1(3 \square)$ & $13(3 \square)$ \\
\hline$\square(1 \square \square)$ & $1 \square(\square \square \square)$ & $25(66 \square)$ & $6(16 \square)$ & $6(16 \square)$ & 0 & \\
\hline $2(5 \square)$ & $5(13 \square)$ & $\square(1 \square)$ & $15(3 \square)$ & $13(3 \square \square)$ & $2(5 \square)$ & $15(3 \square \square)$ \\
\hline $1(3 \square)$ & $3(\square \square)$ & $\square(11 \square)$ & $12(32 \square)$ & $11(2 \square \square)$ & $10(26 \square)$ & $21(55 \square)$ \\
\hline 0 & $\square(21 \square)$ & & $15(3 \square \square)$ & $11(2 \square \square)$ & $3(\square \square)$ & $1 \square(3 \square \square)$ \\
\hline 0 & $3(\square \square)$ & & $\square(21 \square)$ & $20(53 \square)$ & $6(16 \square)$ & $26(6 \square \square)$ \\
\hline $2(5 \square)$ & $12(32 \square)$ & $1 \square(3 \square \square)$ & $3(\square)$ & $15(3 \square \square)$ & $5(13 \square)$ & $20(53 \square)$ \\
\hline $3(\square \square)$ & $5(13 \square)$ & $\square(21 \square)$ & $6(16 \square)$ & $1 \square(\square \square)$ & $6(16 \square)$ & $23(61 \square)$ \\
\hline$\square(1 \square \square)$ & $13(3 \square \square)$ & $20(53 \square)$ & $10(26 \square)$ & $\square(11 \square)$ & $2(5 \square)$ & $6(16 \square)$ \\
\hline $5(13 \square)$ & $1 \square(50 \square)$ & $2 \square(63 \square)$ & $6(16 \square)$ & $6(16 \square)$ & 0 & \\
\hline $5(13 \square)$ & $11(2 \square \square)$ & $16(\square \square)$ & $3(\square)$ & $\square(2 \square \square)$ & $\square(21 \square)$ & $1 \square(\square \square)$ \\
\hline $5(13 \square)$ & $6(16 \square)$ & $11(2 \square \square)$ & $\square(2 \square)$ & $6(16 \square)$ & $10(26 \square)$ & $16([2 \square)$ \\
\hline
\end{tabular}

30. I receive help from my fello $\square$ students.

31. I thin $\square$ there are too many tests given.

32. I am not used to ta ing multiple choice tests. I prefer essay e $\square$ ams

33. I should only be graded on $\square$ ritten $\square$ or $\square$, not on my class participation.

$3 \square \quad$ I feel it is rude to as $\square$ uestions during class.

35. I am afraid people $\square$ ill thin $\square \mathrm{I}$ am stupid if I as $\square$ uestions in class.

36. I am afraid my classmates $\square$ ill thin $\square$ I am stupid if I as $\square$ them $\square$ uestions.

$3 \llbracket \quad I$ as $\square$ my professors for help.

3ॅ. I as $\square$ my classmates for help.

UN D SD D \& SD NR

3ॅ. I as $\square$ only international students from my home region for help and support.

$\square$ I I ma $\ulcorner$ fre $\sqsubset$ uent use of academic support services (tutoring).

\section{$\mathbf{S}$}

1. $\square$ hat else could the university do to support you academically $\square$ See appendi $\square \square$.

\section{Do you have any other comments about your linguistic or educational needs? See appendix E.}


$\square$ ppendi $\square$ C: Countries of $\square$ rigin

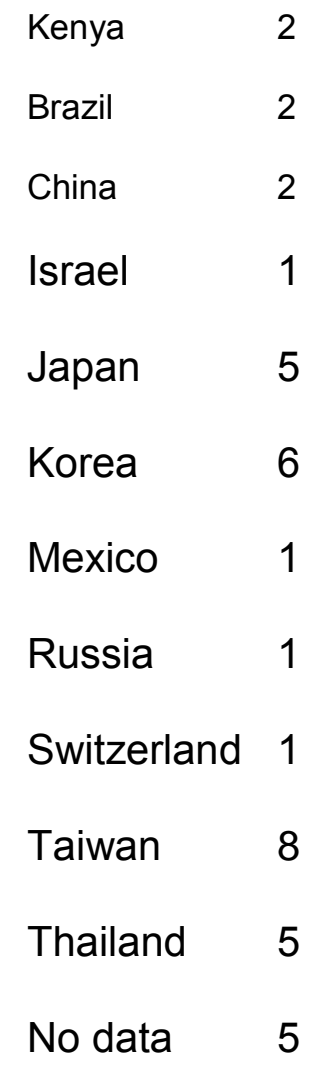




\section{$\square$ ppendi $\square$ D: Native Languages}

\begin{tabular}{|c|c|}
\hline Chinese & \\
\hline Haya & \\
\hline Hebre $\square$ & \\
\hline apanese & \\
\hline$\square$ orean & \\
\hline Portuguese & \\
\hline Russian & \\
\hline Spanish & \\
\hline Su $\square$ uma & \\
\hline $\mathrm{S} \square$ iss & \\
\hline Thai & \\
\hline$\square$ ietna & \\
\hline
\end{tabular}

No data 2 
International Students' Comments

The follo $\square$ ing comments by international students have been reproduced here $\square$ ithout editing, e $\square$ actly as the students $\square$ rote them.

Comments Regarding the Question: "Any other comments about your English language proficiency?"

"Have more chance to communicate with native American."

"Writing well is most difficult."

"I have no problems in reading and understanding but when it comes to write in English and speak up in class, it is difficult."

Comments Regarding the Question: "If you would like to further explain any of your responses from the statements above, please do so here.

"I think DU's most professors are still unaware of the difference between $\square$ merican students $\square$ foreign students.

"I think it is unfair that the international student don't really get work study, since it is the only place for us to $\square$ or $\square$ The financial aid office should $\square$ no $\square$ that the most of the international students here don't get more than $3000 \$$ a year scholarship only so are basic payers of the school."

"I understand all of study materials because of the dictionary. It's impossible to survive as an international students without it!!! In Japan, we don't have much presentation and discussion compare to here. Therefore, it's hard to speak up in the class, even though I have class in Japan."

"It is tough to speak up in front of the class especially because I am shy. I am afraid to ma $\ulcorner$ e mista $\square$ es and my pronunciation. $\square$ hen it comes to $\square$ rite, I usually ta $\_$longer than my normal to remember the right $\square$ ords that e $\square$ press $\square$ hat I really want to say on the essays. My essays don't quite express what I want to say." 
"It's hard to participate in a discussion in the class, and also I sometimes feel so sorry for other students since I ta $e$ a time to say even a short comment. I feel like I'm stealing and wasting their time."

Comments from Part D - Other General Needs/Comments:

What else could the university do to support you academically?

Do you have any other comments about your linguistic or educational needs?

"International Student Services at a previous school:

1. $\square$ ee $\square$ y free $\square$ nglish conversation class.

2. International student advisors $\square$ counselors

3. Weekly "coffee hour" sponsored by the international student group to build supportive environment for the international students and to offer opportunities for other students to meet international students.

․ Conversation partner program.

Dominican:

1. $\square$ hen I entered to school as a graduate student there $\square$ as no orientation by school for international or graduate students.

If there had been any orientation that helped foreign students to understand about differences or difficulties in living and studying in a different culture, that $\square$ ould have made it easier for me to survive.

2. I tried to get some help for my $\square$ nglish, and could not find anything.

3. I felt isolated since I didn't have any opportunity to meet other international students who had the same experience or struggles."

"When I came to the United States I used to feel I lived by myself and relationship $\square$ as not $\square$ orth much because my first friendship $\square$ ith an $\square$ merican $\square$ as very bad. I used to thin $\square$ no one understood me, no one cared about me, and I needed to survive the real $\square$ orld by myself. I also used to trust only myself. It is ambiguous but at the same time I also felt strong needs for connection $\square$ ith others. I felt lonely and $\square$ anted to be $\square$ ith someone. Ho $\square$ ever, I realized later that at the time, many people encouraged and supported me. I finally realized that I $\square$ as not alone, even though at the time I felt alone. I learned a lot that they helped me and no one lives $\square$ ithout connection $\square$ ith others. The e $\square$ perience helped me to gro $\square$. No $\square \mathrm{I} \square$ ant to help others li $\llbracket$ e they helped me. I e $\square$ perienced the struggle and pain $\square$ hen I moved to $\square$ ards gro $\square$ th. It $\square$ as very hard to do everything and to be here. I did not $\square$ no $\square$ real $\square$ merican culture and made mista es and got hurt because of the cultural differences. These $\square$ ere so painful and I $\square$ as afraid to do anything, even though I tal $\square$ ed $\square$ ith people first. Ho $\square$ ever, I ept challenging myself again and again, and finally did not feel the pain anymore and was able to expand my experience." 
"When professors mention many difficult word. I can't understand what the mean is. I $\square$ ant to remember these $\square$ ords from te tboo $\square$ but I have too many pages I should read. I don't have much time too improve my vocabulary skill (listening and speaking)."

"I hope that we have a assistant whose major is the same with me. If we have any question we can ask the guy!"

"I really hope I can have more time to get long $\square$ ith $\square$ merican because I $\square$ no $\square$ I should spend a lot of time to prepare class every day."

"I hope that the university helps us more than now. We don't feel close to the university. $\square \mathrm{e} \square$ ant the university to listen. I hope that $\square \mathrm{e}$ have meeting $\square$ ith our advisors and other school staffs. Or we have a little meeting with other students."

"I hope that I have more opportunities to study English with tutors like communication and pronunciation."

"Let all faculty know about the disadvantage of international students. There is always something that we can't achieve even after we try hard or work hard. They also need to $\square$ no $\square$ the advantage of having international students in their classes. They should make much of this opportunity!"

"I have had the best english teacher since I got here. Mrs. $\square$ al $\sqsubset$ er is enthusiastic, challenging and more then any thing helpful and friendly. She made me have fun writing, something I hated before."

"There should be a writing lab. A place where foreign students can correct their assignments. $\square$ lso, Dominican does not have an International Student Club or alliance. Personally, that $\square$ ould be an a $\square$ esome addition to the Dominican e $\square$ perience. $\square$ place $\square$ here foreign students can connect and get the support they need."

"Help international students $\square$ ith more $\square$ or $\square \square$ e can not $\square$ or $\square$ out side school, and the resources in $\square$ or $\square$ study grant are limited. $\square$ e are coming from places $\square$ here it is much more cheep to go to school. $\square$ e spend a lot more on U.S. education. $\square$ e are $\square$ illing to $\square$ or $\square$ but $\square$ e can not."

"More and better tutorial service. (Current one is very limited.) Cross cultural training for professors. Free conversation classes for international students. International student coffee hour (socializing)."

"Maybe the professors could leave it optional for international students to tal $\square$ spea $\square$ up in classes $\square$ ith native spea $\square$ ers. I mean, classes $\square$ ith native 
spea ers and international students, the professors could leave it optional for the international students to speak up."

"My English is getting better as time goes by."

"Financial aid should have butget for international students! We also need support and e tra money since everythig is very e pensive here, and international students are far from home and need even more money for things. (boo $\ulcorner$ s, household, T.V., etc.)."

"I'd like to have more tutoring services for any subject. Dominican needs more support for international students, such as state university has."

"I get everything I need from D.U.C."

"I wonder why there is no really foreign language program $\square$ ere you could learn different language, this is more for domestic student but if they $\square$ ould learn a different language it $\square$ ould bring international and domestic students closer together."

"Open extra writting or speaking classes after regular ones. More jounal and magazines in the library for doing paper reference."

"Set up volunteer tutors to correct our papers."

"I think the university should have more student adviser for international students. Sometime my adviser doesn't know anything."

"Listening is a big challenge for international students. I suggest school provide some help regarding this issue."

"Creating more ways of student life."

"Free tutoring. That's the most need for us."

"I need somebody to proofread my paper." 
Needs of International Students 65

\author{
$\square$ ppendi $\square \mathrm{F}$ \\ Letter of Introduction to Participants \\ $\square$ nd Consent to Participate in $\square$ nonymous Survey Research
}


Needs of International Students 66

\author{
$\mathrm{L} \square \mathrm{TT} \square \mathrm{R} \square \mathrm{F}$ INTR $\square \mathrm{DUCTI} \square \mathrm{N} T \square \mathrm{P} \square \mathrm{RTICIP} \square \mathrm{NTS}$
}

$\square \mathrm{ND} \mathrm{C} \square \mathrm{NS} \square \mathrm{NT} \mathrm{T} \square \mathrm{P} \square \mathrm{RTICIP} \square \mathrm{T} \square \mathrm{IN} \square \mathrm{N} \square \mathrm{N} \square \mathrm{M} \square \mathrm{US}$ SUR $\square \square \square \mathrm{R} \square \mathrm{S} \square \square \mathrm{RCH}$

Dear Study Participant:

My name is Lisa Haydon and I am a graduate student in the Division of $\square$ ducation at Dominican University of California. I am also an advisor at Dominican. I am conducting a research project as part of my master's thesis requirements, and Madalienne Peters, $\square$ d.D., Professor of $\square$ ducation at Dominican University of California is supervising this $\square$ or $\square$ I am re $\square$ uesting your voluntary participation in my study, $\square$ hich concerns the academic needs of international students at Dominican University of California.

Participation in this study involves the completion of a $\square$ ritten survey, including some demographic $\square$ uestions to be used for statistical purposes. $\square$ our survey responses $\square$ ill be completely anonymous. Filling out the survey is li ely to ta $e$ appro imately 30 minutes of your time. There $\square$ ill be no costs to you as a result of ta ing part in this study, nor $\square$ ill you be reimbursed for your participation in this study. Choosing to participate or not participate in this project $\square$ ill not affect your full access to advising or academic support services.

$\square$ ou $\square$ ill not be recorded. $\square$ ll subjects $\square$ ill be identified by numerical code only. The master list for these codes $\square$ ill be $\square$ ept by this researcher in a loc $\lceil$ ed file, separate from the surveys. $\square$ nly the researcher and her faculty advisor $\square$ ill see the coded surveys. $\square$ ne year after the completion of the research, all $\square$ ritten and recorded material $\square$ ill be destroyed.

Participation in this survey involves no physical ris $\square$, but may involve some psychological discomfort, given the nature of the topic being addressed in the survey. $\square$ ou $\square$ ill be discussing topics of a semi personal nature and you may refuse to ans $\square$ er any $\square$ uestion that causes you distress or seems an invasion of your privacy. $\square$ ou may elect to stop the survey at any time.

There $\square$ ill be direct benefit to you from participating in this study. The anticipated benefit of this study is a better understanding of the academic needs of international students by Dominican staff and faculty and therefore, of your o $\square$ n academic needs.

If you have $\square$ uestions about the research you may contact me at ( $\square 15) 25 \square 131 \square$. If you have further $\square$ uestions you may contact my research supervisor, Dr. Madalienne Peters at $(\square 15) \square 532 \square 5$ or the IR $\square$ PHS at Dominican University of California, $\square$ hich is concerned $\square$ ith protection of volunteers in research projects. $\square$ ou may reach the IR $\square$ PHS $\square$ ffice by calling ( $\square 15) 25 \square 016 \square$.

If you choose to participate in this study, please fill out the attached survey as honestly and completely as possible. Remember this survey is completely anonymous $\square$ do not put your name or any other identifying information on your survey form.

Participation in research is voluntary. $\square$ ou are free to decline to be in this study, or $\square$ ithdra $\square$ from it at any point.

If you $\square$ ould li $\lceil$ e to $\square$ no $\square$ the results of this study once it has been completed, a summary of the results $\square$ ill be posted on the bulletin board outside the Division of $\square$ ducation office, on the second floor of $\square$ ertrand Hall after May 1, 2003.

Consent:

I have been given a copy of this consent form to eep.

My signature belo $\square$ indicates that I agree to participate in this study.

\title{
(
}

Subject's Signature

Date of Signature

Signature of Person btaining Consent Date of Signature

Lisa Haydon

( $\square 15)$ 25 $\square 131 \square$

Dominican University of California

$50 \square$ cacia $\square$ venue, San Rafael, C $\square \square \square 01$ 
hesis $\square$ art $\square$

International Student Support at Dominican University of California

Lisa Haydon

Education 5998

June 15, 2003 
Table of contents

International Student Support at Dominican University of California........................................................................ 67

International Student Support at Dominican University of California....................................................................... 69

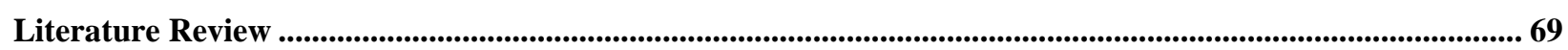

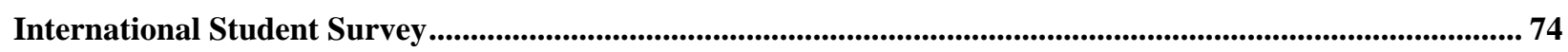

Successful International Student Program Components.............................................................................. 78

Suggestions from International Students At Dominican and Elsewhere ................................................................ 90

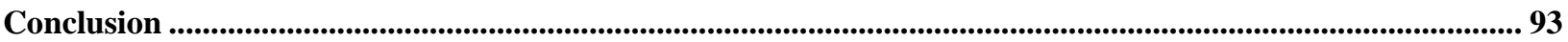

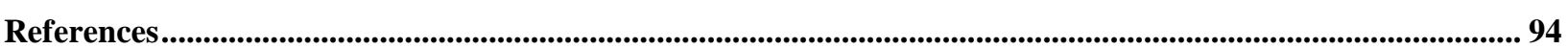




\section{International Student Support at Dominican University of California}

At Dominican University of California, we have a growing international student population.

These students are dedicated, hardworking young people from whom we can learn much. They are cultural ambassadors from diverse world populations who have come to the United States for academic knowledge and personal growth. As a staff member working in Academic Advising and Support, I have interacted with many international students. Over the past five years I have felt moved by these students, by their seriousness, courage, vulnerability, and willingness to learn and grow as people. I wish to offer this work as a means of support for both the international and native student populations as well as the faculty and staff at Dominican University of California, so that we may better facilitate mutual service and learning between all populations, regarding all as both teacher and learner.

\section{Literature Review}

Senator $\square \square$ illiam Fulbright once commented that the purpose of the scholarship program bearing his name was to "bring a little more knowledge, a little more reason, and a little more compassion into $\square$ orld affairs and thereby to increase the chance that nations will learn at last to live in peace and friendship" $(\mathrm{N} \square \mathrm{FS} \square, 2003$, p. 32).

Similarly, four reasons have been given in support of the need for the internationalization of higher education: $\square$ orld peace $\sqsubset$ success in international competition $\square$ global $\square$ no $\square$ ledge $\square$ and global cooperation. $T \square$ o concerns underlie these four rationales: the international interdependence of the United States, and the lack of global awareness among its citizens. An educational institution's goals for internationalization are rooted in needs brought about by global technological 
Needs of International Students $\square 0$

interconnections, global trade, and the resolution of global problems such as pollution, hunger, disease, and terrorism (Schoorman, 2000).

A great asset to any country's efforts to internationalize its educational system is the utilization of its international students. Many international educators agree that international students are an important part of the effort (ibid.). The presence of these students on our campuses allo $\square$ s opportunities for cultural and international understanding. International students, $\square$ hile here to achieve their o $\square$ n personal and academic goals, are al $\square$ ays cultural ambassadors (Sandhu $\neg$ srabadi, $1 \square \square \square$ ). They can assume many roles, serving as educational resources in classroom discussion, counselors for study abroad, guest spea ers on cultural topics, and organizers of cross cultural events (Schoorman, 2000).

\section{Challenges and Stresses Faced by International Students in the United States}

There are many academic, social/cultural, personal/psychological, and environmental challenges and stresses faced by international students. These are brought about by multiple factors: language barriers $\square$ brea $\ulcorner$ s $\square$ ith family and peer support systems (Sandhu $\square \square$ srabadi, $1 \square \square($ ) $\square$ differences in cultural values and assumptions and communication $\square$ and learning styles (Ladd $\square$ Ruby, $1 \square \square \square$ ) $\square$ as $\square$ ell as differences in psychological self $\square$ constructs (Cross, 1995). The process of adaptation of a student is also likely to be related to the "cultural distance" between the norms, values, and customs of the society of origin and those of the receiving society (Tatar $\square$ Horenczy $\square, 2000$ ).

Academic challenges. International students face many academic challenges $\square$ hen studying at colleges and universities in the United States. $\square$ ccording to N $\square \mathrm{FS} \square: \square$ ssociation of International $\square$ ducators (N $\square \mathrm{FS} \square$ ), proficiency in spo $\square$ en and $\square$ ritten $\square$ nglish is the greatest contributing factor to $\square$ ards the academic success of international students (Selvadurai, $1 \square 12$ ). $\square$ et, the most common academic problems pertain to language difficulties (Nicholson, 2001). $\square$ hile many international students are able to pass a standardized proficiency e $\square$ amination in $\square$ nglish, they have difficulty functioning later in an academic setting (Selvadurai, $1 \square \square 12$ ). 


\section{Needs of International Students $\square 1$}

International students have difficulties in understanding lectures, e $\sqsubset$ pressing ideas, and $\square$ riting reports, and these problems have been largely attributed to a lac $\square$ of proficiency in $\square$ nglish (Nicholson, $2001 \square$ Selvadurai, $1 \square \square 12$ ). $\square$ ven though $\square 0$ percent of international students surveyed stated that they had significant difficulty $\square$ ith $\square$ nglish language usage, $\square 0$ percent stated they received no instruction in $\square$ nglish (Nicholson, 2001).

$\square \mathrm{f}$ the four language macro $\mathrm{s} \square$ ills of listening, spea $\square$ ing, reading, and $\square$ riting, $\square$ riting is the $\mathrm{s} \square$ ill that poses the most difficulty for international students. $\square$ esides the challenge of $\square$ riting in grammatically correct $\square$ nglish, students often have great difficulty e $\lceil$ pressing their ideas through $\square$ riting and speech, and at times give the impression that they do not have comple $\square$ ity or depth to their thoughts ( $\square$ riguglio, 2000).

Students often e $\lceil$ press having problems reading te $\llbracket$ ts in $\llbracket$ nglish, especially specialized te $\llbracket$ ts, stating that they find it time consuming and difficult (Nicholson, 2001). They fre $\square$ uently have problems reading $\square$ hat is $\square$ ritten on the blac $\square$ board in class. $\square$ ecause international students may have trouble listening to and understanding fast $\square$ paced, e $\llbracket$ tended lectures, they also have difficulty ta $\square$ ing notes in class ( $\square$ riguglio, $2000 \square$ Par $\square$ er, $1 \square \square$ ).

Learning styles often play a role in difficulties encountered by international students. $\square$ ften, international students are slo $\square$ in adjusting their learning styles to the style of $\square$ merican education (Selvadurai, $1 \square \square 1$ ). This can affect their ability to learn, to receive help, and to convey $\square$ no $\square$ ledge to the professor, all of $\square$ hich $\square$ ill negatively affect their learning e $\llbracket$ perience and academic progress ( $\square$ riguglio, 2000).

Furthermore, students are often shy about spea $\square$ ing up. Many feel their spo $\square$ en $\square$ nglish is not fluent enough for the demands of the classroom ( $\square$ riguglio, 2000). In technical, research oriented, or pedagogical courses, international students may lac $\square$ the vocabulary to phrase coherent $\square$ uestions or comments. $\square$ c $\square$ uiring ne $\square \square$ nglish $\square$ ords related to these areas re $\square$ uires e $\_$tended time and patience on the part of both the student and faculty (Par $\lessdot$ er, $1 \square \square)$.

Many international students are trained to listen to instructors rather than to spea $\square$ in class. In some cultures, instructors are seen as bearers of absolute truths and therefore should not be $\square$ uestioned. In the United States, students are invited to challenge their instructors and enter into debates. $\square$ ften the more casual classroom style can be disturbing. (Selvadurai, $1 \square \square 12$ ).

International students often have difficulty as $₫$ ing for help (Ladd $\square$ Ruby, $1 \square \square$ ). Shyness and passivity in the classroom, as $\square$ ell as a preference to $\square$ ards collectivism rather than individualism, often interfere $\square$ ith students' willingness to independently reach out. Students may feel that putting their individual needs above the 
class needs or standing apart from the group in re $\square$ uiring personal attention in class, is inappropriate (Cross, $1 \square 5$ ). They may also feel that it is shameful to as $\square$ for help from the professor and that they should be able to succeed independently (Ladd $\square$ Ruby, $1 \square \square \square$ ). Students may e $\square$ uate not $\square$ no $\square$ ing an ans $\square$ er $\square$ ith losing face and being humiliated. They may be afraid to loo $\square$ inept in front of the teacher or peers, especially $\square$ ith feelings of inade $\square$ uacy in using a second language ( $\square$ easley $\square$ Pearson, $1 \square \square$ ). Ho $\square$ ever, international students have also been found to prefer to receive instruction through listening and to cultivate close relationships $\square$ ith their professors (Ladd $\square$ Ruby, $1 \square \square \square$ ).

$\square$ ccording to $\square$ easley $\square$ Pearson, $(1 \square \square \square$ ) another factor in academic learning is cross cultural $\square$ riting and thin $\square$ ing styles. Students in the United States are e $\square$ pected to present their arguments in the $\square$ nglish tradition of the strictly linear, logical development of ideas. The different $\square$ riting styles bet $\square$ een cultures involve different ideas of the responsibilities of the $\square$ riter and reader. Chinese, $\square$ orean, and $\square$ apanese cultures place a much greater responsibility on the reader to interpret the message that the $\square$ riter may only imply, yet not logically state in a linear manner. In addition, there are different patterns of ordering and structuring the $\square$ ritten information presented.

estern tradition places much emphasis on comparing, discussing, and evaluating arguments, and students are e $\llbracket$ pected to e $\lceil$ press vie $\square$ points rather than simply duplicating an authoritative opinion. Critical analysis is expected in United States' universities. However, this change in behavior can be very difficult for students $\square$ ho have been educated to practice rote learning and memorization, and $\square$ ho seldom $\square$ uestion the teacher or the te tboo $\square$ In many countries, each subject of study at a university may have only one te $\downarrow$ and only offer one point of vie $\square$ to the student ( $\square$ easley $\square$ Pearson, $1 \square \square$, personal communication, 2000). Ho $\square$ ever, many educational researchers feel that this is an outdated stereotype and challenge this vie $\square$ point ( $\square$ easley $\square$ Pearson, $1 \square \square)$.

Factors such as course structure, content, and academic standards can all be impediments to the academic goals of international students in the United States (Selvadurai, $1 \square 12$ ). Instructional techni $\square$ ues such as discovery learning may seem inappropriate, foreign, and inefficient $\square$ ays of learning. $\square$ ther factors of the estern educational system that international students have identified as problematic are home $\square$ or $\square$ grading differences, and teachers $\square$ ho are perceived as rude, $\square$ ho do not ta $\square$ e e $\square$ tra time $\square$ ith students, and $\square$ ho may use $\square$ hat students feel is inappropriate or vulgar language (Par $\lceil$ er, $1 \square \square \square$ ). 
Social/cultural and personal/psychological challenges. International students are regarded as a population psychologically at ris $\square$ This is due to immediate and often drastic changes in social, cultural, and environmental factors in the lives of international students upon arrival in the United States. When students' processes of adaptation are not ade $\sqsubset$ uately facilitated by the host school, a range of personal and psychological problems arise. $\square$ study of international students from more than 50 different countries found that students reported higher than normal problems in the areas of an ¿iety, depression, psychosomatic symptoms, and paranoia (Tatar $\square$ Horenczy $\square, 2000$ ).

Stressors that play major roles in mental health crises of international students include the follo $\square$ ing: culture shoc $\square \mathrm{e}\lceil$ pressed through an $\sqsubset$ iety, depression, hostility, tension, frustration, an $\square$ iety, anger, and stress $\square$ societal e $\llbracket$ pectation for high academic performance $\sqsubset$ changes in social and economic status e $\llbracket$ pressed through feelings of resentment and loss $\square$ and feelings of discrimination, alienation, and isolation (2000 Nicholson, 2001Tatar $\square$ Horenczy $\square$ ). $\square$ ccording to Sandhu $\square \square$ srabadi (1 $\square \square$ ), homesic $\square$ ness, loneliness, fear, and pessimism are also major concerns.

Language difficulties, $\square$ hile playing a major role in academic problems, also contribute to personal and social problems. $\square$ eing understood is associated $\square$ ith feelings of acceptance and appreciation. Confusion, frustration, depression, and lo $\square$ self esteem are the results of not being understood. Language difficulties may lead international students to see $\square$ relationships $\square$ ith those $\square$ ho spea $\square$ their first language, thus hampering integration into $\square$ merican social groups (Nicholson, 2001). $\square$ merican students may be complacent $\square$ ith their situation and not feel the need to go out of their $\square$ ay to socialize $\square$ ith foreign students (Sandhu $\square \square$ srabadi, $1 \square \square \square$ ).

$\square$ ften international students are una $\square$ are of cultural differences in friendship building and dating eti $\square$ uette, along $\square$ ith other $\square$ mericans customs related to food habits, religious beliefs, and nonverbal communication (Selvadurai, 1 $\square \square$ 1). International students may see $\square$ to fit into $\square$ merican social groups by changing their behavior and attitudes. This can lead to guilt and also undermine personal identity and self respect. $\square$ ll this leads to acculturative stress (Sandhu $\square \square$ srabadi, $1 \square \square \square$ ). The follo $\square$ ing is a $\square$ uote from one of Dominican University of California's international students (written report, 2003). This gives a good summary of the many difficulties our students face:

When I came to the United States I used to feel I lived by myself and relationship was not worth much because my first friendship with an American was very bad. I used to 
think no one understood me, no one cared about me, and I needed to survive the real world by myself. I also used to trust only myself. It is ambiguous but at the same time I also felt strong needs for connection with others... I did not know real American culture and made mistakes and got hurt because of the cultural differences. These were so painful and I was afraid to do anything, even though I talked with people first. However, I kept challenging myself...and finally did not feel the pain anymore and was able to expand my experience (p. 1).

\section{International Student Survey}

In February of 2003 this researcher developed and distributed an academic needs assessment to all international students at Dominican University of California. The results of this assessment are presented here. These results form the basis for the recommendations put forth in this paper.

\section{Summary of Major Findings}

Of the 55 surveys distributed, 38 were returned. All surveys were used. The usable return rate was 69 percent. All respondents were international students attending Dominican University of California.

Part A of the survey addressed demographic information. Some information was not completed due to the respondent's desire to remain anonymous. Fifty-four percent of respondents were women, 42 percent were men, and 4percent did not identify their gender. The respondents ranged in age from 19 years to 27 years ( $M=23$ years). The average length of time spent in the United States was 18.5 months and the average length of time at Dominican was 14 months. The length of time speaking English ranged widely from 2 months to 15 years. Thirty percent of the respondents were graduate students, 59 percent were undergraduates of whom 24 percent were freshman, and 11 percent did not respond to this question. Sixty-eight percent of respondents were from Asia, 19 percent were from a wide range of countries in the Americas, Europe, and Africa, and 13 percent gave no data. 
Part $\square$ of the survey addressed the $\square$ nglish language proficiency of international students. Concerning the question, "How would you rate your English proficiency in the following?" four areas were addressed: listening/understanding, spea $\square$ ing, reading, and $\square$ riting. In the category of listening/understanding, 60 percent rated themselves as either e $\lessdot$ cellent (22

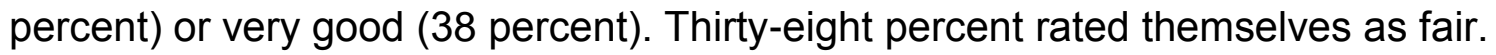
Concerning spea $\square$ ing, $\square 0$ percent rated themselves as either e $\leftarrow$ cellent (16 percent) or very good (2 $\square$ percent). Ho $\square$ ever, $5 \square$ percent rated themselves as either fair ( $\square$ percent) or poor (1 $\square$ percent). In the area of reading, $\square 0$ percent responded that they $\square$ ere e $\sqsubset$ cellent or very good $\square$ hile $3 \square$ percent rated themselves as fair. $\square$ riting s $\square i l l s ~ \square$ ere lo $\square$ est, $\square$ ith $6 \square$ percent of the respondents rating themselves as either fair or poor.

Part $\mathrm{C}$ of the international student survey was composed of 40 questions. These questions addressed academic skills applied to the following: students' classroom participation; relationships with faculty and peers; ability to understand and complete assignments and exams; and recourse to academic support services.

Seventy five percent of all students surveyed responded that they understood most of $\square$ hat their professors said in class lectures. Ho $\square$ ever, 16 percent felt that professors spo $\sqsubset$ e too $\square$ uic $\square$ ly $\square$ hen lecturing. Seventy $\llbracket$ nine percent of students surveyed responded that they could understand their professors $\square$ hen they spo $\llbracket$ e personally. $\square$ verall, listening $\mathbf{s} \square$ ills $\square$ ere good and responses $\square$ ere consistent.

Seventy three percent of students responded that they understood most of $\square$ hat $\square$ as $\square$ ritten in their te $\llbracket$ tboo $\square$ s, $\square$ ith $\square \square$ percent stating they understood $\square$ hat $\square$ as $\square$ ritten on the $\square$ hite board in class. It should be noted 
that $\square$ percent of respondents reported that they understood typed handouts the professors gave them. Si ty $\square$ seven percent felt they $\square$ ere able to finish reading assignments on time. Si teen percent felt they could not. $\square$ verall, reading s $\square$ ills $\square$ ere good and responses $\square$ ere consistent.

Regarding $\square$ riting s $\square$ ills, $\square \square$ percent of respondents stated they $\square$ ere able to finish $\square$ riting assignments on time. Ho $\square$ ever, students reported having difficulty $\square$ ith various $\square$ riting tas $\square$ s. Thirty seven percent had difficulty ta $\square$ ing notes in class in $\square$ nglish, and $3 \square$ percent stated they had difficulty $\square$ riting essays, $\square$ ith $\square 2$ percent being uncertain. $\square$ ight respondents (21 percent) felt they did not have difficulty $\square$ riting essays.

$\square$ uestions regarding spea $\square$ ing s $\square$ ills $\square$ ere related to interaction $\square$ ith professors and students in class as $\neg$ ell as out of class. $\square$ nly $3 \square$ percent of students stated they $\square$ ere not afraid to spea $\square$ in class and $\square$ ere not afraid of ma $\square$ ing mista $\square$ es $\square$ hen spea $\_$ing. Thirty seven percent of respondents stated they $\square$ ere afraid they $\square$ ould be perceived as stupid if they as $\square$ ed $\square$ uestions in class and agreed $\square$ ith the statement that they could not e $\lceil$ press their true thoughts in spo $\square$ en $\square$ nglish. $T \square$ enty one percent $\square$ ere afraid to as $\square[$ uestions of their classmates for fear they $\square$ ould be thought stupid. $\square$ f the students $\square$ ho $\square$ ere afraid of spea $\square$ ing up in class, only 3 respondents felt it $\square$ as rude to as $\square \square$ uestions. Ho $\square$ ever, $2 \square$ percent felt it $\square$ as rude to disagree $\square$ ith the professor and $3 \square$ percent of respondents $\square$ ere uncertain.

The last area of consideration $\square$ as resources international students utilized for help. $\square$ hile 65 percent stated they as $\sqsubset$ ed their classmates for help, $\square 2$ percent stated they as $\sqsubset$ ed only international students from their home region for help and support. Thirty four percent of students did not feel comfortable participating in study groups $\square$ ith other students, $\square$ ith $1 \square$ percent being uncertain. Thirty four percent of students stated they sought help through academic support services (tutoring), and $2 \square$ percent stated they made fre $\sqsubset$ uent use of academic support services.

hile $6 \square$ percent of international students felt their professors respected them, only 55 percent felt their professors $\square$ anted to help them, and only $\square 5$ percent felt the professors $\square$ ere $\square$ illing to spend $\mathrm{e}$ tra time helping them. $\square$ nly $\square \square$ percent felt that their academic advisor $\square$ as $\square$ illing to spend e $₫$ tra time helping them.

Fifty three percent of international students stated that they as $\lessdot$ ed their professors for help. $\square$ nly $2 \square$ percent stated that their professors understood their personal and academic challenges, $\square$ hile 53 percent felt their academic advisor 
understood these challenges. Si ty one percent of international students $\square$ anted their professors to $\square$ no $\square$ more about their culture and 50 percent $\square$ anted professors to include more about their culture and e perience in class.

\section{Analysis of Themes}

The areas of strength for the international student population participating in this survey are listening and understanding spoken English and reading and understanding written English. Speaking and writing in English are areas needing more support.

Difficulties in these areas lead to a lack of cultural understanding and utilization of assistance from faculty and students who are not from international students' home countries. A large percentage of international students have difficulty participating verbally in class. This is based on their fear of rejection from others because of poor language skills.

Sixty-nine percent of international students either did not feel that their professors understood them or they were unsure. They were unclear about the level of interest their professors had in giving them extra assistance. One student stated, "I think DU's most professors are still unaware of the difference between American students \& foreign students.” Therefore, a large percentage of students did not ask their professors for help. The students felt that their academic advisors were slightly more understanding of their needs but were not significantly more available than the professors.

International students made moderate use of academic support services and less than a third made use of these services fre $\square$ uently. Some students $\square$ rote comments on their surveys re $\square$ uesting tutoring services, $\square$ hich seemed to indicate that the students $\square$ ere not a $\square$ are that these services $\square$ ere already available to them. There $\square$ as a positive correlation bet $\square$ een strong language s $\triangle i l l s$ and feelings that professors understood and cared for 
the students. There $\square$ as also a positive relationship bet $\square$ een language s $\square$ ills and class participation, as $\square$ ell as the student's ability to interact inside and outside the classroom with students from other countries.

In general, the majority of international students attending Dominican University of California are able to understand class lectures and $\square$ ritten materials and could finish their $\square$ or $\square$ in a timely manner. Students understood $\square$ ritten handouts given in class, $\square$ hich supplemented lectures. Ho $\square$ ever, international students identified $\square$ riting assignments and spea $\square$ ing in the classroom as special challenges.

Many international students have difficulty participating in class discussions or as $\square$ ing $\square$ uestions, and most did not enter into debate $\square$ ith the professor in class. Students $\square$ ere afraid of being perceived as stupid. hen as $\triangle$ ing for help, many international students sought out those from their native country and did not ma $\lceil$ e full use of fello $\square$ classmates, professors, or advisors. $\square$ hile most students $\square$ ere not confident about their $\square$ riting s $\square$ ills, less than half of those students sought support through tutoring.

International students at Dominican University of California need further assistance from faculty, staff, and other students. Communication is the $\square$ ey issue. International students need to $\square$ no $\square$ that faculty and staff are available to them and are interested in learning about their cultures. There is a need to develop and clearly define resources for international students.

Patterns similar to those of other colleges and universities $\square$ ere found at Dominican. Language proficiency $\square$ as positively related to cultural adaptation, social integration, and academic progress. Social integration and cultural adaptation also directly and positively related to academic success. The difficulties that $\square$ ere reported by international students at Dominican University of California are therefore similar to those reported by international students at colleges and universities throughout the United States. It can thus be assumed that the components of successful international programs used at other institutions of higher learning $\square$ ill be applicable and useful at Dominican University of California.

\section{Successful International Student Program Components}

Based on the review of the literature concerning international students at colleges and universities, as well as on the results of the Dominican University of California International Student Needs Assessment, this researcher has complied recommendations for Dominican University of California. NAFSA, as well as other institutions of higher learning, have many guidelines and 
suggestions for excellent international student programs. I will discuss these suggestions and guidelines and comment on which of these Dominican University of California could adopt.

\section{NAFSA Guidelines for International Students Programs}

General re $\sqsubset$ uirements for serving international students have been put forth in the Handboo $\square$ of $\square$ ccreditation (2001). In summary, these guidelines re $\square$ uire that the educational institution must demonstrate service to international students in a legally and ethically responsible, unbiased, and sensitive manner ( $\square$ ccrediting Commission for Senior Colleges and Universities, 2001). The $\square$ ssociation of International $\square$ ducation $\square$ dministrators ( $\square \square \square$ ) also offers guidelines for international education at U.S. colleges and universities. These guidelines specify that there should e $\_$ist a professional staff that can provide the $\operatorname{re} \leftarrow$ uired support services for international students (Schoorman, 2000).

$\square$ ccording to $\mathrm{N} \square \mathrm{FS} \square$ (2001), programs of international education ta $\_$e many forms and are located at colleges and universities $\square$ ith different purposes, sizes, and settings. Regardless of these differences, it is only $\square$ hen an educational institution ma $\lceil$ es a conscious commitment of resources to its international program that the program $\square$ ill be successful. Underlying such commitment are the follo $\square$ ing institutional principles put for $\square$ ard by $\mathrm{N} \square \mathrm{FS} \square$ presented here in summary. Comments regarding Dominican University of California are incorporated at the end of each section.

1. The institution should have a clearly stated policy, endorsed by the governing board, $\square$ hich includes goals and objectives of the international student program developed by the institution. The policy should include planning and budget considerations. Personnel and resources $\llbracket$ both administrative and academic $\llbracket$ should be sufficient to assure that the program can be operated in $\square$ ays that are consistent $\square$ ith the principles put forth in the document.

Dominican's governing board needs to develop clear goals and objectives in regards to planning and budget considerations. Personnel and resources must be increased for the Office of International Student Services and other departments that serve the international student population.

2. The e $\lceil$ ecutive staff of the institution should discuss $\square$ ith the faculty and administrative staff the implications of the international program policy for the academic programs and staff.

At Dominican, this has begun and must continue and increase. The executive staff must not only discuss policy but create a plan for implementation of changes. 
3. Programs should be closely related to and consistent $\square$ ith the purposes and strengths of the institution. More services are needed. In the first sentence of the Dominican University of California mission statement, Dominican is referred to as an international university. This must mean more than the fact that we have some international students in attendance. It must mean that our programs take into account the needs of these students and that we offer a truly international education to all of our students.

$\square$ Regardless of program size, the institution should ac $\square$ no $\square$ ledge its responsibility to demonstrate sensitivity to cultural needs - social, religious, dietary, and housing. These must be accounted for in the planning and e ecution of the program.

Dominican takes many needs of international students into account. Student housing is arranged so that international students cohabitate with American students. In general, faculty is respectful of students and extra tutoring time is available to international students. There is an effort being made to diversify curriculum. However, assistance with intercultural communication must be addressed more directly. International students suffer from cultural and personal isolation and an inability to understand interdependency as a key part of relationships with faculty, staff, and fellow students on this campus.

5. Services should be performed by personnel $\square$ ho are trained for their particular responsibilities. Faculty and staff should receive appropriate training for the activities they manage.

Training for faculty and staff at Dominican is ongoing and should continue. VPAA and CLIENT workshops take place on a regular basis. Individual departments make use of conferences off campus. More education specific to international student needs should be offered in the future.

6. Staff and faculty should develop and maintain respect and sensitivity to $\square$ ards those of different cultures.

According to the results of the International Student Needs Assessment (Haydon, 2003), faculty and staff are respectful but must increase their sensitivity towards and knowledge of those of different cultures. This may be due to the need for faculty and staff to allow more time for small group or one-onone interaction with international students.

$\square$ The institution should periodically evaluate programs, policies, and services, and program goals.

Dominican is in the midst of reevaluating its international student program. This research project is part of that reevaluation process. Reevaluation must be followed by practical and sufficient change. 
The admissions process. $\square$ ny international program begins $\square$ ith the recruitment and admission of students. N $\square \mathrm{FS} \square$ (2002) has put forth principles of good practice for these processes. The goal of the international admissions process is to identify, attract, and admit $\sqsubset$ ualified students $\square$ hose educational goals fit ell $\square$ ith the mission and offering of the recruiting institution. Staff $\square$ or $\square$ ing to $\square$ ard the admission of international students should have specialized $\square$ no $\square$ ledge, $\mathbf{s} \llbracket i l l s$, and resources, and professional judgment.

The admissions office should have a strong commitment to student service and development, a clear understanding of the institution's mission, policies, and standards, an ability to clearly communicate with prospective international students and recruits, and conduct outreach in an ethical manner. The admissions office should understand the processes and re $\square$ uirements of the immigration regulating branches of the U.S. government and responsibly manage record $\sqsubset$ eeping according to accepted professional standards. The department must also consider the differences in document issuing practices around the $\square$ orld and evaluate documentation accurately and fairly, $\square$ hile effectively coordinating its efforts $\square$ ith other offices involved in the admissions process for international students (N $\square \mathrm{FS} \square, 2002$ ).

The Admissions Office at Dominican University of California fulfills the above requirements. However, this office should work more closely with the Office of International Student Services to provide more support for international students, once they have expressed an intention to attend. This support includes pre-arrival information and better orientation and personal service to international students beginning at the time of deplaning in the United States.

International student services. $\square$ s stated in $\mathrm{N} \square \mathrm{FS} \square$ documentation (2001), it is the responsibility of the host institution to meet the needs of its international students in an organized, directed, and funded manner. Regardless of the number of international students present on campus, the college or university is re $\sqsubset$ uired to offer a basic level of support that enables the student, once accepted into the institution, to be successful. The follo $\square$ ing $\mathrm{N} \square \mathrm{FS} \square$ principles support these services.

1. The host institution should clearly state its intentions to provide special support services to international students. These services should include advisement and counseling, mandated and technical services in compliance $\square$ ith U.S. government regulations, and coordination and liaison $\square$ ith the community.

This is not now occurring at Dominican and must be implemented. International students do not have special advisors that are educated in the problems they face. If international students miss 
orientation they may miss vital immigration information. Many international students spend little or no time making use of resources such as tutoring because they have not understood what has been said in orientation. There is too much information conveyed in a short period of time for a second language learner to comprehend and absorb. Small group orientations that repeat information and allow for question and answer are needed.

Many international students suffer extended culture shock because there are no counselors or advisors who are trained and specifically designated to serve this population. Advisors are assigned according to the department of the student's major. International student counselors are needed at Dominican. One Asian student told me she frequently cries at her desk because she feels there is no one she can talk to at Dominican about her cultural difficulties. I invited this student to come talk to me. However, she is a senior and is graduating. Intervention should have been offered much sooner.

Counseling offered by the counseling psychology department is most often not appropriate. These students do not need this type of counseling and the counselors are most often not trained in this type of intervention. International students need to be clearly informed that if they are having difficulties they may talk with Dr. Wes Young and he will arrange for counseling or advisement. At the present time Lisa Haydon is the only other advisor specifically designated for this function. At orientation, students are not told about this opportunity.

2. There must be one unit in the host institution responsible for coordinating these services $\square$ ith clear and ac $\square$ no $\square$ ledged designation of responsibility for these services. This must occur regardless of the number of international students present at the institution or level of funding.

The Office of International Student Services at Dominican is comprised of the director, Dr. Wes Young. Dr. Young works in coordination with Simona Getz in the Office of the Registrar as well as Lisa Haydon in Academic Advising and Support Services. It would be appropriate to either add more staff or else designate existing staff and faculty to directly assist Dr. Young, while remaining in their current departments. Clear and acknowledged designations of responsibility should be put in place. The Office of International Student Services should be given a realistic operating budget; at the time of this writing the department has no budget. 
3. $\square$ n orientation program should be in place that introduces students to the physical environment, registration procedures, academic policies, housing, counseling and health services, visa re $\square$ uirements and INS regulations, and financial matters. Social and intercultural activities should be offered. $\square$ dvising services should be provided on an ongoing basis $\square$ ith respect to personal counseling, emergency needs, and preparation for departure and reentry to home countries.

Orientation at Dominican must be improved, beginning before departure from the home country and continuing on campus in a more detailed and specialized manner. Students should be sent or should be able to download off the Dominican web site an International Student Handbook. Students should be met at the airport and taken to their dormitories. Orientation to the campus, counseling, tutoring, and health services should be given in small groups with a questions and answer period. Students should also be part of a larger freshman orientation in order to help them integrate with classmates. Departmental orientations could also be offered. Social and intercultural activities should be further developed on the campus.

$\square$ The staff and faculty $\llbracket$ should maintain high ethical and professional standards.

In general, Dominican's faculty and staff meet these criteria. However, there have been reports of faculty behavior that has been interpreted by the international and ALANA student populations as lacking in professional conduct. This includes rude remarks and continued insensitivity toward students.

Educators. N $\square \mathrm{FS} \square$ (2001) has many guidelines for international student educators. $\square$ mong them are:

1. $\square$ no $\square$ ledge of the cultural adjustment process.

Dominican faculty needs to be more aware of which students are international and help to facilitate the cultural adjustment process and well as academic progress.

2. Counseling and advising s $\leftarrow$ ills.

International student counselors and advisors need to be available to meet the unique needs of this population. These students need to know with whom they can talk to facilitate the transition to a new language, culture, and environment. The students must be able to discuss intercultural communication and customs, areas that students suffer. Faculty members also act as academic advisor. These faculty members should examine their role as advisors in light of the unique needs of international students. Awareness of these needs and the use of strategies to meet them are responsibilities of faculty advisors. 
Correct placement into classes, continued contact with the student throughout the semester, and recommendations for tutoring and other academic support should be incorporated into the advisory role. The student should feel supported by the advisor and that the advisor is an ongoing resource for the student.

3. $\square \square$ areness of ho $\square$ culture and language influence learning styles.

A high percentage of international students reported in a recent international student survey (Haydon, 2003) that incompatibility of learning styles was not a problem at Dominican. However, there are many classroom techniques derived from various teaching styles that can prove helpful to international students. Some of these are the use of typed lecture outlines given to students at the beginning of class, small group discussion with peers and instructors, and mentoring relationships and assignments among students.

$\neg$. no $\square$ ledge of learning another language, educational systems other than those in the U.S, and cultural values and assumptions and their effect on interactions $\square$ ith individuals and groups.

The faculty and staff at Dominican University of California should feel a responsibility to broaden their knowledge of the above. Campus-wide training sessions, that would include all departments, could be held as a part of professional development once or twice a year for this purpose.

5. Intercultural communication s $\square$ ills.

At Dominican University of California the first step is to identify those students who are from a different culture. The next step is to make the campus community aware of the need to extend themselves to this population. It is important to allow international students to take an active role in educating our community in their customs and ways of communicating, thus allowing them to act as ambassadors for their countries. We, in turn, can help international students become knowledgeable about appropriate ways to communicate in our country. The key is for community-wide participation with international students. An academic course for international students on intercultural communication that would include American cultures and customs would also be appropriate. This course could include American students who wish to study abroad and mentoring relationships could be established. 
$\mathrm{N} \square \mathrm{FS} \square$ provides grants to colleges and universities, $\square$ hose staff and faculty develop model programs to support international students. Final reports about these programs can be obtained free of charge (N $\square \mathrm{FS} \square$, $1 \square \square)$.

Dominican University of California should consider applying for some of these NAFSA grants as a way to creatively develop aspects of its international student program. Dr. Wes Young should spearhead these projects and include a wide population of students, faculty, and staff. This is an exciting opportunity that should not be ignored since it provides funding for needed improvements to our international student program.

\section{Summary of Successful Components}

\section{$\underline{\text { Successful }}$}

\section{Components of}

\section{Student Services}

Services to international students are best coordinated through the $\square$ ffice of International Student Services. Services should include pre arrival information and assistance, orientation activities, ongoing advisory services, advocacy and intervention, and the development of programs that enhance interaction bet $\square$ een students and members of the academic community. Pre arrival information can be organized in a variety of $\square$ ays. Programs or information on a variety of topics pertaining to life in the United Stated can be offered by agencies such as governmental, private institutions, or alumni groups in the home country, or by the United States institution, using a variety of multilingual media. This includes printed information pac $\lessdot$ ets, brochures, videos, $\mathrm{t} \square$ enty four hour message systems, electronic mail, and the $\square$ orld $\square$ ide $\square$ eb. (Schoorman, 2000).

Orientation for international students is one of the most common forms of international student services offered by colleges and universities. It typically includes immigration information, an introduction to university requirements and services, and an introduction to the community, focusing on cross-cultural differences. An academic and discipline-specific orientation with the participation of faculty members is strongly recommended (Schoorman, 2000). Summer bridge programs have been created whereby international students come for the summer prior to their first semester at the university 
and engage in activities that focus on cultural adjustment as well as academic and language skills (Kezar, 2000). Weekend orientation retreats designed for international students have also been found to be more effective than single day orientations where all new students are addressed (NAFSA, 1999).

All of these activities should be developed at Dominican University of California, coordinated through the Office of International Student Services with the Office of Admission, Academic Advising and Support, and faculty and staff. At the present time, we offer orientations for international students that are blended with American students. A separate international student orientation follows some weeks later that concentrates on immigration law. At the present time, bridge programs are being developed by the Director in International Student Services, Lisa Haydon in Academic Advising and Support, and the director of the independent English language school on the Dominican campus, Dr. Dean Wright. These programs will serve both cultural and academic needs of our prospective international students, current international students, as well as those American students wishing to participate in study abroad programs.

$\square$ ngoing advising services uni $\square$ ue to international students include immigration advising, cross cultural counseling, social and cultural adaptation, and preparation for departure and return. Counseling services should be designed to help alleviate culture shoc $\square$ and homesic $\llbracket$ ness, and promote understanding of cultural differences bet $\square$ een the social norms of their home country and the U.S., and adaptation to the U.S. educational. $\square$ ngoing advising services uni $\square$ ue to international students include immigration advising, cross cultural counseling, social and cultural adaptation, and preparation for departure and return (Schoorman, 2000).

\section{Successful academic components.}

Several international educators have indicated that faculty members are the most crucial players in the process of successful internationalization of a university, and therefore, of the success of its international students. Many faculty members $\square$ ho have e $\square$ pertise in this area are underutilized. Most $\square$ ill need to develop e $\square$ pertise, and several strategies have been suggested. These include $\square$ or $₫$ shops on international issues, incentives such as release time and stipends for curriculum development, the study of a foreign language and culture, and opportunities to teach abroad and for involvement in e $₫$ tra $\square$ curricular international activities. $\square$ oth 


\section{Needs of International Students}

faculty and staff must become globally literate and cross culturally sensitive. Professional development $\square$ or $\backsim$ shops, attendance at national and international conferences, and the active recruitment of internationally oriented personnel are all important (Schoorman, 2000).

Currently at Dominican, faculty may travel to $\square$ urope and $\square$ sia for personal and professional enrichment. Ho $\square$ ever, this can be increased as $\square$ ell as organized $\square$ ith more of a focus on cultural education for purposes of better understanding the cultures of our $\mathrm{o} \square \mathrm{n}$ international students. There is a diverse population of faculty and staff at the university and $\square$ or $₫$ shops should be developed that can provide faculty and staff $\square$ ith cultural information. Instructors from the $\square$ nglish language school housed at Dominican can be invited to spea $\square \square$ ith our faculty and help them understand the uni $\sqsubset$ ue needs of international students.

International students can help educate faculty, staff, students, and the surrounding community. These students must be given opportunities to serve as educational resources in classroom discussions, as peer and study abroad counselors, as guest spea ers on cultural topics, and as organizers of cross cultural events (Schoorman, 2000). This $\square$ ill help lead faculty, staff, and students to intercultural adaptability, including listening s $\square$ ills and the ability to interpret behavior and apply social or e $\llbracket$ periential learning in different cultural conte $₫ s$ ( $\square$ eszotars $\square$, 2001).

Currently at Dominican, $\square$ e do not have an organized program that coordinates these activities. It is up to the individual student or instructor to initiate classroom activities and most often this does not occur. The $\square$ ffice of International Student Services should coordinate $\square$ ith faculty deans and chairs to initiate classroom activities and the international student services department itself should initiate study abroad and peer counseling.

In the classroom. The classroom environment is the main arena in which international students' needs must be recognized. There is a need for clear and comprehensive instructions about academic assignments $\square$ ith timely diagnostic feedbac $\square$ During lectures, the e tended use of overhead transparencies and printed lecture notes or lecture outlines are helpful to international students. Professors should spea $\square$ slo $\square$ ly and clearly, $\square$ ithout the use of slang, and $\square$ rite clearly on the board. Students benefit from teaching styles that incorporate practical e $\lceil$ amples to illustrate theoretical concepts and use modeling and coaching of metacognitive strategies ( $\square$ easley $\square$ Pearson, $1 \square \square \square \square$ riguglio, 2000).

$\square$ ngoing curriculum development at some universities has transformed courses from traditional teacher $\square$ directed courses involving lectures and tutorial in $\square$ hich students are relatively passive. Changes produced 


\section{Needs of International Students}

shorter but more fre $\square$ uent lectures, $\square$ ith either more fre $\square$ uent meeting times or e tended class times that progressed at a slo $\square$ er pace. $\square$ or $\llbracket$ shop type formats that allo $\square$ the student to be a more active and self directed learner are being incorporated at many schools (Par $\sqsubset$ er, $1 \square \square \square \square$ alas, 2000). Groups designed to increase cultural mi $\square$ ing serve to undermine the tendency to self segregation. More presentations may be re $\square$ uired of students (Trice, 2001). Field trips incorporated into curricula enhance cultural and historical understanding (N $\square \mathrm{FS} \square, 1 \square \square$ ). $\square$ learner support program utilizing both faculty and peers is also effective ( $\square$ easley $\square$ Pearson, $1 \square \square \square$ ). For those courses in $\square$ hich class participation is factored into the final grade, some professors allo $\square$ good participation to enhance student performance but do not lo $\square$ er the grade if class participation is infre $\square$ uent ( $\square$ alas, 2000$)$.

Ladd and Ruby $(1 \square \square)$ suggest that since many foreign students are accustomed to class lecture $\square$ ith minimal participation, the instructor can begin to slo $\square$ ly introduce open $\_$ended $\square$ uestions that re $\sqsubset$ uire opinion, problem solving, and decision ma ing. If these concepts are introduced immediately, international students may be uncomfortable and fearful. The instructor should build the students' self confidence and trust. Thin $\sqsubset$ ing on your feet e $\sqsubset$ ercises such as $\square$ uestions regarding simple self $[$ description to describing an object and progressing to hypothetical $\square$ uestions the student must ans $\square$ er, can be used. In addition, offering students tips in class on ho $\square$ to study or utilize a certain ne $\square$ learning style is helpful.

It has been recommended that at the beginning of the term, instructors should also meet $\square$ ith international students after class, specifically to discuss methods of teaching, e $\leftarrow$ pectations, and class rules. According to Ladd and Ruby, "The classroom is not a place to play the game of 'let's see if the students can figure out the rules'; it is a place where cognitive and affective growth can-and should—flourish" (1999, p. 6). Instructors should be careful $\square$ hen using idioms that the student may ta $\ulcorner$ literally instead of figuratively. For example, the phrase, "quite a few..." may mean simply "few" to the student instead of "many" (Ladd \& Ruby, $1 \square \square)$.

It is the job of the $\square$ ffice of International Student Services to act as a liaison bet $\square$ een the international student and the instructor. The student should feel that his or her needs could be voiced and discussed $\square$ ithout fear in this $\square$ ay. The $\square$ ffice of International Student Services should also be in contact $\square$ ith the international student's academic advisor, if the advisor is not already affiliated with that department.

Outside of the classroom. $\square$ cademic assistance and support can be offered through tutorials and tutoring sessions, seminars on communication and study s $₫$ ills, and one to one consultation and support, all 
geared toward the international student's unique needs (Briguglio, 2000). This is provided by the Department of Tutoring, part of the Department of $\square$ cademic $\square$ dvising and Support, $\square$ hich liaisons $\square$ ith the $\square$ ffice of International Student Services. Upon the start of classes, each international student should be assigned a $\square$ riting tutor $\square$ ho can be contacted directly for academic support. International student study s $₫ i l l s$ or $\square$ shops can be offered. In the fall of 2003, Lisa Haydon and Maria Mc $\square$ inney $\square$ ill begin offering these $\square$ or shops to international students at Dominican. $\square$ learning center is also being developed $\square$ hich $\square$ ill provide $\square$ eb and computer based tutorials for international students.

In general, a broad dialogue bet $\square$ een international students, faculty, and native students is very important. Informal discussions, in $\square$ hich international students e $\llbracket$ press their academic e $\llbracket$ pectations and concerns, could be valuable ( $\square$ alas, 2000). $\square$ hen communication difficulties arise, it is usually more comple $\square$ than just language problems because language is intert $\square$ ined $\square$ ith culture. Therefore, $\square$ hen intercultural communication ta es place, it is important for all parties to ta $\_$into account differences in past e periences, behavioral norms, beliefs, and body language (Trice, 2001). $\square$ t Dominican, the $\square$ ffice of International Student Services, in coordination $\square$ ith the student leadership, should create activities such as conversation clubs, international student coffee hours, and other mechanisms for interaction bet $\square$ een students, faculty, staff, and international students.

\section{Successful Cultural/Personal and Psychological Components}

Researchers agree on three functional aspects of social support: emotional, involving intimacy, concern, and attachment $\sqsubset$ instrumental, involving provision of assistance $\square$ and informational, involving the provision of information or guidance relevant to the situation (Tartar $\square$ Horenczy $\square, 2000$ ).

Developmental educators, educational psychologists, and sociologists agree that peer group interactions form a significant bonding that shapes students' social and academic integration as well as their institutional commitment. Students $\square$ ho are more personally satisfied through forming strong partnerships $\square$ ith peers and institutional staff and teaching faculty, and $\square$ ho participate in school and community related activities, have a higher retention rate. Positive e $\square$ periences and e $\square$ pectations $\square$ ithin a peer group are associated $\square$ ith high academic performance. Institutional programs that facilitate the formation of connections $\square$ ith an individual student, a group, or an institution as a whole may improve the international student's experience of and 


\section{Needs of International Students $\square 0$}

persistence at the university, regardless of the demography of the student (I $[$ egulu, $1 \square \square]$ ). There is much opportunity at Dominican to develop more positive cultural and social e $\lceil$ periences for our international students. I propose a meeting to $\square$ hich all international students are invited, to be hosted by the Departments of International Student Services, Student Life, $\square$ cademic $\square$ dvising and Support, and student leadership. Ideas can be discussed as to ho $\square$ to develop various programs and activities.

ithin the academic setting, diverse study teams in $\square$ hich international students are encouraged to spea $\square$ out can be assigned in order to avoid culture shoc $\square$ (Reingold, $1 \square \square$ ). The internationalization of social/cultural events on campus is an important aspect of an international campus. T $\square$ o successful outcomes $\square$ ill be that students of all cultures feel $\square$ elcome and positive intercultural communication and intermingling becomes the norm. $\square \| l$ administrators, faculty, and students $\square$ ould be a $\square$ are and appreciative of the cultural diversity of the campus and actively become involved in facilitating cross cultural interaction. Faculty and staff can as $\square$ international students affiliated $\square$ ith their departments $\square$ hat events $\square$ ould most interest them. The students can be dra $\square \mathrm{n}$ into the planning of these events. If students are uncomfortable participating $\square$ ith the large groups, smaller events can be planned specifically for them (Trice, 2001).

$\square$ ther events can involve the entire campus community, not just a specific department. Some e $\sqsubset$ amples of these types of events are the formation of student organizations, international food fairs, dances, plays, film festivals, music recitals, and poetry readings. Cross cultural forums on a variety of international and personal topics can be organized as $\square$ ell as $\square$ ee $\sqsubset$ end retreats (N $\square \mathrm{FS} \square, 1 \square \square$ ). These events are often organized by the students themselves (Schoorman, 2000).

\section{Suggestions from International Students at Dominican and Elsewhere}

International students have suggestions $\square$ hat they feel $\square$ ill help them succeed at U.S. post secondary institutions. The follo $\square$ ing is a list of these suggestions and summaries of student comments (Haydon, 2003 $\square$ Nicholson, 2001).

1. Class size should be small. This allo $\square s$ for more opportunity to e $\lceil$ press oneself to the professor and to tal $\square$ more $\square$ ith students in discussion groups. In large groups, students spea $\square \square$ uic $\square$ ly to allo $\square$ for more students to participate. Smaller classes allo $\square$ for a rela $\lceil$ ed atmosphere.

2. Students should be invited to social events such as potluc $\square$ dinners. 
3. $\square$ merican students should help in finding research articles, provide transportation, and help in other $\square$ ays $\square$ ithout being as $\square$ ed. They should be friendly, tal $\square$ to international students, invite them to their homes for dinner, and offer housing during times $\square$ hen students cannot live in the dormitories. They should allow the students to visit the American student's friends and relatives in other places when they travel.

$\neg$. Professors should ta $\lceil$ e time to listen to international students and to sho $\square$ an understanding of their cultures in class discussions.

5. Professors should have more office hours.

6. Professors should spea $\square$ slo $\square$ ly in class, use simpler vocabulary, print or use good hand $\square$ riting on the board, and distribute handouts of their lecture notes.

$\neg$. Professors should $\sqsubset$ eep promises, invite international students to dinner, and develop relationships $\square$ ith them.

$\square$ The $\square$ ffice of International Student Services should operate in the follo $\square$ ing $\square$ ays: It should help but not control the students $\square$ help $\square$ ith employment problems $\square$ provide a counseling center only for international students to deal $\square$ ith homesic $\square$ ness and interpersonal relations $\square$ ma $\square$ e available a place to stay $\square$ hen students arrive $\sqsubset$ and notify the student beforehand about transportation to campus from the airport. The office should e $\lceil$ ercise its authority $\square$ hen addressing academic problems and provide support for international students in communicating their problems to various departments.

$\square \square$ ee $\square$ y free $\square$ nglish conversation class.

10. International student advisors $\square$ counselors

11. Weekly "coffee hour" sponsored by the international student group to build a supportive environment for the international students and to offer opportunities for other students to meet international students.

12. Conversation partner program.

13. $\square$ rientation by school for international and graduate students.

$1 \square \square$ orientation that helps foreign students understand the differences or difficulties in living and studying in a different culture.

15. Help $\square$ ith time management, vocabulary improvement. 
16. Teaching assistants in class to help students.

$1 \square$ Structured social time $\square$ ith $\square$ merican students.

18. English language tutors to help with spoken English.

19. More frequent meetings with advisors, faculty, and other students.

20. Listen to international students more. Appreciate what they have to offer.

21. A writing lab.

22. Form an international student club or alliance where foreign students could connect.

23. Increase work-study for international students. Many are very poor and they cannot work off campus.

24. Increase and expand tutoring services.

25. Cross-cultural training for professors.

26. International student coffee hours where international students could meet American students.

27. Do not make speaking in class grade dependent. Give international students the option of speaking less in class.

28. Having a foreign language program would afford American students a more multicultural understanding and bring international and American students closer. It would allow international students to teach and share with American students.

29. Offer more journals and magazines in the library for research and acculturation.

30. Peer advisors for international students.

31. Better informed faculty advisors.

32. Proofreading services for international students. 
Needs of International Students $\square 3$

\section{Conclusion}

Dominican University of California see $\llbracket$ s to build relationships $\square$ ith countries around the $\square$ orld, sharing its ideals or pillars of contemplation, study, service, and community, $\square$ ith all. Diversity and internationalism are important characteristics to Dominican and are highly valued. Therefore, Dominican see $\ulcorner$ to recruit students from countries throughout the $\square$ orld and to provide these students $\square$ ith a superior educational and cultural e $\llbracket$ perience. Dominican values the $\square$ no $\square$ ledge these students bring to the campus community and therefore invites them to act as ambassadors of their cultures and teachers of the Dominican community.

In order to fulfill this mission, Dominican University of California must continue to e amine and develop its international student services and to measure itself against the highest standards in this area. $\square$ hile Dominican is succeeding in many areas, there is much to be done. The process of adaptation for international students is a great challenge and is more difficult the greater the cultural distance bet $\square$ een the host and home country. Since Dominican is inviting international students to its campus, there must be a demonstrated commitment to addressing and resolving the real and multifaceted challenges faced by these students.

ddressing the needs of the international student population is a matter of practical and simple solutions. Language is the primary obstacle to adaptation in academics as $\square$ ell as social, cultural, and personal areas and can be addressed through mentoring relationships, learning labs, tutoring, and classroom assistance. Differences in learning, $\square$ riting, and test ta $\square$ ing styles can be resolved through increased interaction $\square$ ith instructors, fello $\square$ students, and the student support services.

Intercultural communication can be facilitated through international counselors, diversified course $\square$ or $\square$, international student clubs, cultural events, and mentoring relationships. Through these means international students $\square$ ould be given a firm foundation for forming friendships and for participating successfully in the classroom. Faculty advisors and instructors must identify and ta e a greater role in supporting international students. In general, the entire process from recruitment of international students to their graduation must be developed and roles and responsibilities clarified and funded.

I have attempted to offer a comprehensive summary of means by $\square$ hich Dominican University of California may development into the international university it see $\triangleleft s$ to be. Dominican has an e $\sqsubset$ cellent group of staff and faculty $\square$ ho are committed to diversity and to providing the best education possible for all people. Change ta $\ulcorner$ es time, funding, commitment, and patience. $\square$ e have the means and it can be done. 


\section{Needs of International Students}

\section{References}

$\neg$ alas, $\square$. (2000). Using participation to assess students' knowledge. [Electronic version $\square$ College Teaching, 48( $\square), 12$.

$\neg$ easley, C. $\square \square$ Pearson, C. $\square$. L. (1 $\square \square)$. Facilitating the learning of transitional students: Strategies for success for all students. $\square$ lectronic version $\square$ Higher Education Research \& Development, 18(3), 30321.

$\square$ riguglio, C. (2000). Language and cultural issues for $\square$ nglish as $\square$ Second/Foreign Language students in transnational educational settings. Higher Education in Europe, XXV (3), $\square 25233$.

Cross, S. $\square$. (1 $\square$ ). Self construals, coping, and stress in cross cultural adaptation. Journal of Cross-Cultural Psychology, 26(6), $6 \varangle 3 \square \square$.

Haydon, L. (2003). Meeting the Needs of International Students at Dominican University of California. Master's thesis. Dominican University of California

I $\sqsubset$ egulu, T. N. (1 $\square \square)$. Multicultural and Globalized Education: International Students' Perspective. Reports $\square$ Research No.1 $₫$ 3. Department of $\square$ ducational Leadership, College of $\square$ ducation, Grambling State University.

ezar, $\square$. (2000). Summer bridge programs: Supporting all students.

$\square$ lectronic version $\square$ ERIC Digest. $\square$ RIC Clearinghouse on Higher $\square$ ducation, $\square$ ashington, D.C. $\square \square \square 1566 \square$

Ladd, P. Ruby, R. (1 $\square \square$ ). Learning style and adjustment issues of international students. $\square$ lectronic version $\square$ Journal of Education for Business, 74(6) $1 \square 10$.

$\mathrm{N} \square \mathrm{FS} \square(1 \square \square$ ). Cooperative Grants Program - Model Program List. Retrieved une 20, 2002, from http:// $\square \square \square$.nafsa.org/coop.

$\mathrm{N} \square \mathrm{FS} \square$ (2002). Cooperative Grants Program - Model Program List. Retrieved une 20, 2002, from http:// $\square \square \square$.nafsa.org/coop.

$\mathrm{N} \square \mathrm{FS} \square$ (2002). Important Data on International Education Exchange To and 
From the United States. Retrieved $\sqsubset$ une $\square, 2002$, from

http:// $\square \square \square$.nafsa.org/content/PublicPolicy/DataonInternational $\square$ ducation/FactSheet.htm.

$\mathrm{N} \square \mathrm{FS} \square$ (2001). NAFSA's Principles for Institutions. Retrieved May 2দ, 2002 from

http:// $\square \square \square$.nafsa.org/content/InsideN $\square \mathrm{FS} \square / \square$ thicsandStandards/Principles

Institutions.htm.

$\mathrm{N} \square \mathrm{FS} \square$ (2001). NAFSA's Principles for International Student and Scholar Services.

Retrieved May 2দ, 2002 from

http:// $\square \square \square$.nafsa.org/concent/InsideN $\square$ FS $\square$ / thicsandStandards/Principls

ScholarServices.htm.

$\mathrm{N} \square \mathrm{FS} \square$ (2002). NAFSA's Principles of Good Practice for the Recruitment and

Admission of International Students. Retrieved May 2দ, 2002 from

http:// $\square \square \square$.nafsa.org/contentN $\square \mathrm{FS} \square / \square$ thicsandStandards/Principles $\square \mathrm{DS} \square \mathrm{C} . \mathrm{htm}$.

$\mathrm{N} \square \mathrm{FS} \square$ (2002). The U.S. Presidents on Fulbright and International $\square$ change Programs. Retrieved $\square$ une $\square, 2002$, from

http:// $\square \square \square$.nafsa.org/content/ $\square$ boutInternational $\square$ ducation/Resources/Presidents. htm.

Nicholson, M. $\square$. (2001). Adaptation of Asian students to American culture.

(Reports - Research No. 1₫3) Indiana University South $\square$ end.

Par $\sqsubset$ er, D.R. (1 $\square$ ). Teaching, learning, and working with international students:

A case study. (Paper presented at the $\square$ nnual meeting of the Mid South $\square$ ducational Research

$\square$ ssociation $2^{\text {th }}$, Point Clear, $\square$ L, November $1 \square 1 \square, 1 \square \square \square$ ). (Reports - Research No. 1凸3.) Louisiana

Tech University.

Sandhu, D.S. $\square \square$ srabadi, $\square$. R. (1 $\square \square \square$ ). Development of an acculturative stress

scale for international students: Preliminary finding. $\square$ lectronic version $\square$ Psychological Reports, 75, $35 \square$

Schoorman, D. (2000). How is internationalization implemented? A framework

for organizational practice. (Information $\square$ nalysis No. $0 \square 0$ ). Florida $\square$ tlantic University, Department of Teacher $\square$ ducation.

Selvadurai, R. (1 $\square \square$ 1). Problems faced by international students in $\square$ merican 
Colleges and universities. $\square$ lectronic version $\square$ Community Review, 12(1/2), 16.

Tatar, M Horenczy $\square$ G. (2000). Counseling students on the move: The effects

of culture of origin and permanence of relocation among international college students. $\mathbb{\square l e c t r o n i c}$ version $\square$ Journal of College Counseling, 3(1), 115.

Trice, $\square$. G. (2001). Faculty Perceptions of Graduate International Students: The Benefits and Challenges. ( $\square$ valuative report $\square 1 \square$ 2). Purdue University, Department of $\square$ ducational Studies.

$\square$ eszotars $\square$ i, P. (2001). $\square$ RIC revie $\square$ : Issues in global education initiatives in the community college. ஐlectronic version [Community College Review, 29(1), 111. 